\title{
Inoculation of native symbiotic effective Sinorhizobium spp. enhanced soybean [Glycine max (L.) Merr.] grain yield in Ethiopia
}

Diriba Temesgen ${ }^{1 *}\left(\mathbb{D}\right.$ and Fassil Assefa ${ }^{2}$

\begin{abstract}
Background: Soybean [Glycine max (L) Merr.] is an annual leguminous crop serving as a source of food and feed, green manure, biodiesel and fiber. It is nodulated by diverse slow growing and fast growing rhizobia belonging to the genus Bradyrhizobium and Sinorhizobium, respectively. In Ethiopia, it has been cultivated since 1950s with lower grain yield history. Yield improvement efforts have been more concentrated on agronomic studies, inoculation of exotic Bradyrhizobium japonicum including TAL379 and/or fertilizer application. The results have usually been unsatisfactory and inconsistent. This study was initiated to identify promising indigenous soybean rhizobial inoculant that can enhance yield of the crop in the country.

Methods: Native soybean rhizobia, designated GMR for Glycine max rhizobia, were trapped using soybean (cv. EthioYugoslavia) from soils collected across agro-ecologies of Ethiopia. They were screened for in vitro tolerance against physico-chemical stresses, plant growth promoting (PGP) traits and symbiotic performances at greenhouse and field levels. A reference B. japonicum (TAL379) was included in all experiments. A soybean plant growth promoting Achromobacter sp. was also included in field trials for co-inoculation. Quantitative data were assessed by analysis of variance (ANOVA) employing SAS computer software package version 9.3. Mean separations were undertaken using Duncan's Multiple Range Test at $p \leq 0.05$. Phenotypic variability of the test bacteria was undertaken using PAST4.03 Computer Software.

Result: GMR that produced acid and grew faster with larger colonies were identified as Sinorhizobium spp. and those which produced alkali and grew slowly with smaller colonies were identified as Bradyrhizobium spp. though further genetic analysis should be performed for verification and identification of their genus and species, respectively. Two Sinorhizobium spp. (GMR120C and GMR125B) profoundly nodulated different soybean cultivars under greenhouse conditions and significantly improved grain yield ( $p \leq 0.05$; maximum 3.98 tons ha ${ }^{-1}$ ) compared to $2.41,2.82$ and 2.69 recorded as maximum grain yield (tons $\mathrm{ha}^{-1}$ ) for TAL379 inoculation, positive control and negative control, respectively in field trials. Higher yield was recorded when GMR125B was co-inoculated with Achromobacter sp., but when GMR120C was inoculated singly. These GMR also showed efficient utilization of numerous substrates, some PGP traits and potential adaptation to various ecological stresses.
\end{abstract}

Conclusion: The two Sinorhizobium spp. (GMR120C and GMR125B) are promising soybean inoculants that can be used to enhance the productivity of the crop in the country.

Keywords: Ethiopia, Native sinorhizobium, Soybean, Stress tolerance, Nodulation, Grain yield

\footnotetext{
*Correspondence: direteme@gmail.com

${ }^{1}$ Department of Biology, College of Natural and Computation Sciences,

Madda Walabu University, P.O.Box 437, Bale Robe, Ethiopia

Full list of author information is available at the end of the article
}

\section{Background}

Soybean is an annual leguminous crop which was initially domesticated in East Asia, and is principally cultivated in North and Latin America at present time. It has 
been cultivated in Africa since 1896 (Shurtleff and Aoyagi 2009). It is one of the top internationally important crops serving as a nutritious food and feed, source of biodiesel and fiber (Scott and Aldrich 1983; Yi-you 2004; Ogbemudia et al. 2010). It is also used as green manure to improve soil fertility due to its ability to symbiotically fix atmospheric nitrogen with different species of Bradyrhizobium, a slow growing genus of rhizobia (Kuykendall et al. 1992; Xu et al. 1995; Appunu et al. 2008; Yang and Zhou 2008; Zhang et al. 2012) and species of Rhizobium, $a$ fast growing genus of rhizobia (Keyser et al1982; Scholla and Elkan 1984; Chen et al. 1988,1995; Saldana et al. 2003). Chen et al. (1988).reclassified fast growing soybean rhizobia as Sinorhizobium. It is also known to be associated with diverse groups of plant growth promoting rhizobacteria (PGPR) (Masciarelli et al. 2014).

Soybean [Glycine max (L.) Merrill] establishes effective symbioses with Bradyrhizobium, principally with strains belonging to $B$. japonicum and B. elkanii (Hungria et al. 2001). Some fast growing strains of soybean rhizobia which were as effective as slow growing counter parts were also reported (Dowdle and Bohlool 1985, Isreal et al. 1986; Hungria et al. 2001). Inoculation of soybean with its rhizobia can improve the growth and yield of the crop (Sharma and Kumawat 2011; Solomon et al. 2012; Rechiatu et al. 2015; Ulzen et al. 2016). PGPR inoculations, usually with Bradyrhizobium japonicum, increased seedling emergence rate (Le' on et al. 2009), nodulation, $\mathrm{N}$-fixation and grain yield of soybean (Dashti et al. 1998; Argaw 2012; Aung et al. 2013; Kravchenko et al. 2013). To achieve better inoculation response, screening of rhizobia is important as they vary in their symbiotic effectiveness, compatibility to various soybean cultivars and ecological adaptation.

In Ethiopia, soybean has been cultivated since 1950s expanding into different agro-ecologies accompanied by increasing domestic demand as food and feed yet with low grain yield (Hailu and Kelemu 2014). Recently, Deresse (2019) indicated the availability of 26 released varieties of soybean in the country. The Ethiopian CSA (2019) also reported the production of the crop on $64,720.12$ hectares with $149,454.6$ tons of grain yield (2.31 tons ha ${ }^{-1}$ ) which was low due to poor soil fertility (Argaw 2012) and ineffectiveness of exotic commercial bradyrhizobia (Aserse et al. 2012).

Indigenous soybean rhizobia was first recovered from Ethiopian soil in 1980's (Abebe 1986). However, more attention has been given to agronomic studies, inoculation of exotic B. japonicum including TAL379 and/or fertilizer application rather than screening native rhizobia. Genetic characterizations (Aserse et al. 2012; Jaiswal et al. 2016; Fana 2018), evaluation of green house and field symbiotic performance (Argaw 2014) and determination of inherent antibiotic resistance (Abera et al. 2015) are some of the studies that have been carried out on indigenous soybean rhizobia in the country. The studies have indicated predominantly the presence of Bradyrhizobium spp. (and few clustering with Rhizobium) and good nodulation of some varieties of soybean, but with low grain yield records. The studies have included limited ecological regions and rhizobial traits. Moreover, no promising native soybean inoculant has been established in the country. Therefore, this study was initiated to isolate soybean rhizobia from soils collected from various regions of the country and screen for in vitro potential ecological adaptation and for symbiotic performance under green house and field conditions so as to develop better inoculant of the crop.

\section{Materials and methods}

\section{Soil sampling, bacterial isolation and reference strain}

Slightly acidic (pH 5.9 to 6.4) composite soil samples with no previous history of inoculation were collected from different agro ecological regions of Ethiopia (Fig. 1) with altitude ranging from 1055 to $1875 \mathrm{~m}$ above sea level (masl). Surface sterilized soybean seeds [cv. Ethio-Yugoslavia; $2 \%$ sodium hypochlorite (Lwin et al. 2012)] were sown into each soil sample in $3 \mathrm{~kg}$ capacity disinfected plastic pots (70\% ethanol). Plants were grown for 45 days with the provision of distilled sterile water when required and uprooted for nodule collection. Nodules were surface sterilized ( $4 \%$ sodium hypochlorite), crushed and the resulting suspensions were streaked on yeast extract mannitol agar (YMA) plates and incubated for 10 days at $28{ }^{\circ} \mathrm{C}$ (Somasegaran and Hoben 1994). Isolated bacteria were designated GMR (Glycine max rhizobia), checked for purity via subculturing and preserved at $4{ }^{\circ} \mathrm{C}$ on YMA (Vincent 1970). Pure cultures were authenticated on the host plant under greenhouse conditions following standard methods (Somasegaran and Hoben 1994). Authenticated GMR were subjected to determination of various cultural, physiological and symbiotic traits. A Bradyrhizobium japonicum strain (TAL379 or USDA 136b), obtained from National Soil Testing Center of Ethiopia, was included in all laboratory, green house and field experiments as a reference.

\section{Determination of colony morphology, acid/alkali production and generation time}

GMR were streaked on YMA plates to determine colony size (mean diameter of five colonies), shape and margin, texture, appearance and gum production according to Lupwayi and Haque (1994). They were also streaked on YMA-BTB (0.5\% Bromothymol blue) plates to assess color change as an indication of acid or alkali production. Tests were carried out in triplicates streaking a loopful of 


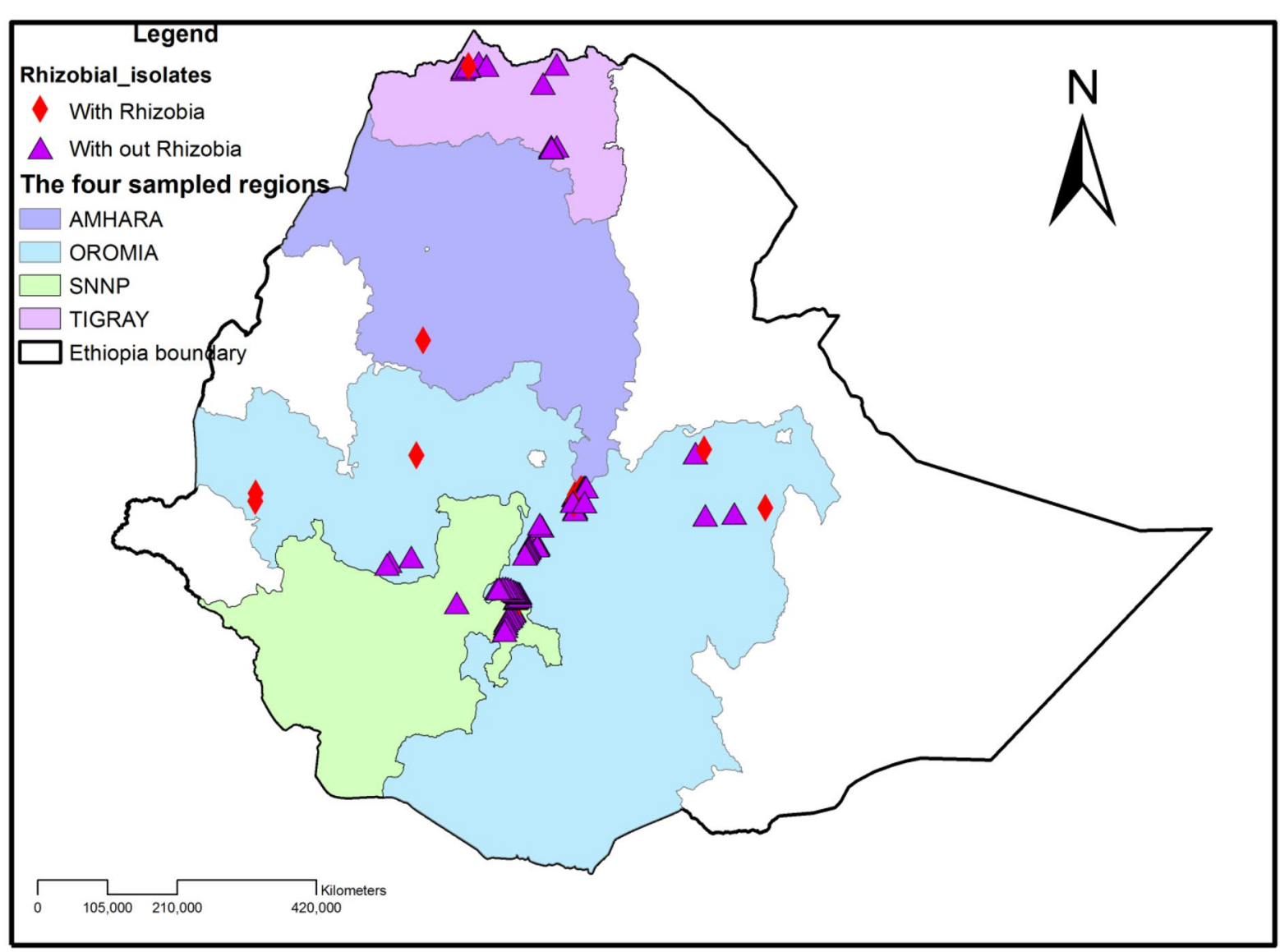

Fig. 1 Map of Ethiopia showing soil sampling sites identified as those with or without soybean rhizobia

active yeast extract mannitol broth $(\mathrm{YMB})$ culture $(10 \mu \mathrm{L}$; $10^{6}$ cells $\mathrm{mL}^{-1}$ ) followed by incubation at $28 \pm 0.2{ }^{\circ} \mathrm{C}$ for 7 days.

To determine the generation time $(\mathrm{g})$, each actively growing YMB culture $(10 \mathrm{~mL})$ was transferred into $100 \mathrm{~mL}$ of sterile YMB in a $250 \mathrm{~mL}$ Erlenmeyer flask and shaken at $150 \mathrm{rpm}$ [orbital shaker: Gollen hamp, England; room temperature $\left(20-30{ }^{\circ} \mathrm{C}\right) ; 72 \mathrm{~h}$ ]. Samples were taken every $2 \mathrm{~h}$ to determine optical density (OD ${ }^{540}$; Jenway, $6405 \mathrm{Uv} /$ vis spectrophotometer) and colony forming units (cfu) according to Somasegaran and Hoben (1994). Eventually, the generation time (g) was computed from log phase according to White (1995).

\section{Testing for tolerance against physico-chemical stresses}

Growths of all the GMR at various levels of salt $(\mathrm{NaCl})$, temperature and $\mathrm{pH}$ as well as in the presence of antibiotics, heavy metals and pesticides were assessed as follows. YMB cultures were separately streaked on YMA plates (amended with 0.5 to $6 \% \mathrm{NaCl} ; \mathrm{w} / \mathrm{v}$ ) and on Keyser-defined medium plates ( $\mathrm{pH} 4,4.5,5,8.5,9,9.5$ or 10) and incubated at $28 \pm 0.2{ }^{\circ} \mathrm{C}$ (Lupwayi and Haque 1994).
They were also streaked on YMA plates and incubated at $35^{\circ} \mathrm{C}, 37^{\circ} \mathrm{C}, 40^{\circ} \mathrm{C}$ and $45^{\circ} \mathrm{C}$ wrapping with parafilm ${ }^{\circledR}$ to minimize moisture lose in evaluating higher temperature tolerance.

YMB cultures of the GMR were streaked on YMA

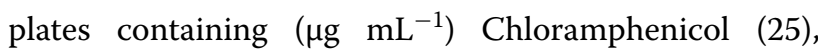
Streptomycin sulfate (10), Erythromycin (100), Ampicillin (200), Gentamycin (20), Nalidixic acid (100), Penicillin G (200), Tetracycline (10), Vancomycin (15) and Cifroflaxin (10) to test their inherent antibiotic resistance (IAR) according to Dowdle and Bohlool (1985). They were also streaked on minimal salt agar medium plates (pH 6.8) supplemented with filter sterilized (final concentration, $\mathrm{mM}) \mathrm{CoCl}_{2} \cdot 6 \mathrm{H}_{2} \mathrm{O}(0.5), \mathrm{Pb}\left(\mathrm{CH}_{3} \mathrm{COO}\right)_{2} .3 \mathrm{H}_{2} \mathrm{O}$ (2.5), $\mathrm{K}_{2} \mathrm{Cr}_{2} \mathrm{O}_{7}(0.25), \mathrm{CuCl}_{2} .2 \mathrm{H}_{2} \mathrm{O}, \mathrm{ZnSO}_{4} .7 \mathrm{H}_{2} \mathrm{O}$ and $\mathrm{MnSO}_{4} .4 \mathrm{H}_{2} \mathrm{O}$ (each 0.25 ) to assess their inherent heavy metal resistance (IHR) according to Hungria et al. (2001). The GMR were also tested for their resistance against $0.2 \%[\mathrm{w} / \mathrm{v}]$ of two fungicides (Mankozeb and curzet; Du Pont de Nemour, France) on YMA plates (Mubeen et al. 2006) and against $0.14 \%$ glyphosate (Monsanto Europe S.A, Belgium) on minimal salt agar medium plates 
(Ahemad and Khan 2010). In all the above stress tests, a loopful of each YMB culture $\left(10 \mu \mathrm{L} ; 10^{6}\right.$ cells $\left.\mathrm{mL}^{-1}\right)$ was streaked on a plate and incubated at $28 \pm 0.2{ }^{\circ} \mathrm{C}$ (except for temperature test) for 5-7 days. Eventually, the presence of growth $(+)$ and absence of growth $(-)$ were recorded as tolerant and sensitive, respectively.

\section{Evaluation of carbon and nitrogen substrate utilizations}

A loopful YMB culture of each GMR $(10 \mu \mathrm{L}$; $10^{6}$ cells $\mathrm{mL}^{-1}$ ) was tested for utilization of 19 carbon sources (D-glucose, D-fructose, D-galactose, D-arabinose, D-mannose, xylose, maltose, $\alpha$-lactose, trehalose, D-sucrose, dextrin, inositol, sorbitol, $\mathrm{Na}$-citrate, dextrose, cellobiose, $\mathrm{Na}$-acetate, inulin and sodium propionate) and 13 amino acids (L-Alanine, $\mathrm{L}$-argenine, methionine, DL-phenyl alanine, DL-plolin, leucin, DL-threonine, DLserine, lysine, DL-tryptophan, glycine, L-tyrosine and DL-glutamic acid), each added to a basal medium according to Amarger et al. (1997). Heat labile carbon sources and amino acids were filter sterilized $(0.22 \mu \mathrm{m})$ prior to adding into autoclaved basal medium. Presence $(+)$ and absence (-) of GMR growth were recorded as the ability and inability to utilize a substrate, respectively.

\section{Assessment for plant growth promoting (PGP) traits}

GMR were assessed for in vitro antifungal activity, solubilization of three inorganic phosphates (Tri-calcium-, aluminium- and iron-phosphate), production of indole acetic acid (IAA), HCN and some enzymes. Active loopful YMB culture $\left(10 \mu \mathrm{L} ; 10^{6}\right.$ cells $\left.\mathrm{mL}^{-1}\right)$ of each GMR was spot inoculated on Pikovskaya's medium plates to evaluate their tri-calcium phosphate solubilization trait. Similar spot inoculations were made on NBRIP (National Botanical Research Institute's Phosphate medium, Lucknow, India) plates to assess for solubilization of aluminum phosphate $\left(\mathrm{AlPO}_{4}\right)$ and iron-phosphate $\left(\mathrm{FePO}_{4}\right)$ by substituting $\mathrm{AlPO}_{4}$ or $\mathrm{FePO}_{4}$ for $\mathrm{Ca}_{3}\left(\mathrm{PO}_{4}\right)_{2}$ in NBRIP (Pe'rez et al. 2007). Plates were incubated at $28 \pm 0.2{ }^{\circ} \mathrm{C}$ for 7 days and formation of clear halo around colonies was recorded as phosphate solubilizer. Phosphate solubilization indices (PI) were calculated by dividing the total diameter (halo zone plus colony) to colony diameter $(\mathrm{mm})$.

YMB culture $(100 \mu \mathrm{L})$ of each GMR was transferred into YMB $(5 \mathrm{~mL})$ amended with filter sterilized L-tryptophan $\left(2 \mathrm{~g} \mathrm{~L}^{-1}\right)$ to detect and quantify IAA production (Parray et al. 2013). Cultures were grown on an orbital shaker [Gollen hamp, England; $150 \mathrm{rpm}$; room temperature $\left.\left(20-30{ }^{\circ} \mathrm{C}\right)\right]$ for $96 \mathrm{~h}$, centrifuged $(3,000 \mathrm{rpm}$ for $30 \mathrm{~min}$ ) and $2 \mathrm{~mL}$ of each supernatant was mixed with $4 \mathrm{~mL}$ of Salkowski reagent. The mixtures were kept at room temperature for $25 \mathrm{~min}$ in darkness to measure absorbance at $530 \mathrm{~nm}$ (Jenway, $6405 \mathrm{Uv} / \mathrm{vis}$ spectrophotometer). IAA was quantified using a standard curve of known concentrations of pure IAA (HiMedia) in un-inoculated L-tryptophan amended YMB. Un-inoculated YMB supplemented with L-tryptophan was used as control.

Four YMB cultures of GMR (each $10 \mu \mathrm{L} ; 10^{6}$ cells $\mathrm{mL}^{-1}$ ) were spotted inoculated equidistantly $2 \mathrm{~cm}$ from the center on YMA plates amended with $0.5 \%$ sucrose and incubated at $28 \pm 0.2{ }^{\circ} \mathrm{C}$ for $72 \mathrm{~h}$. A $4 \mathrm{~mm}$ disc of $72 \mathrm{~h}$ potato dextrose agar (PDA) culture of Fusarium oxyporum was placed at the center of the Petri dish and further incubated at the same temperature until fungus in the control plates (plates without bacteria) reached the edges of the plates. Eventually, the percentage of inhibition of radial growth (PIRG) of the fungus was calculated according to Siddiqui and Meon (2009).

YMB culture $\left(100 \mu \mathrm{L} ; 10^{6}\right.$ cells $\left.\mathrm{mL}^{-1}\right)$ of each GMR was spread on YMA plate amended with $4.4 \mathrm{~g} \mathrm{~L}^{-1}$ of glycine to detect $\mathrm{HCN}$ production (Ahemad and Khan 2012). Stripe of Whatman filter paper (No.1) was soaked in picric acid solution and fixed to the underside of the lid of plates. Plates were sealed with parafilm ${ }^{\circledR}$ and incubated at $28 \pm 0.2^{\circ} \mathrm{C}$ for 5 days. Change of the filter paper from yellow to light brown, brown or reddish brown was recorded as weak, moderate and strong $\mathrm{HCN}$ production, respectively.

YMB cultures $\left(10 \mu \mathrm{L} ; 10^{6}\right.$ cells $\left.\mathrm{mL}^{-1}\right)$ of GMR were spot inoculated on nutrient agar plates supplemented with 1.5\% skimmed milk powder (Ryden et al. 1973), Carboxymethyl cellulose (CMC) agar plates (Kasana et al. 2008) and chitin agar plates (Bansode and Bajekal 2006) to evaluate protease, cellulase and chitinase activity, respectively. The plates were incubated at $28 \pm 0.2{ }^{\circ} \mathrm{C}$ for 5 days to detect clear zone formation around colonies. CMC plates were flooded with Gram's iodine for 3-5 min in darkness to visualize halo zones.

\section{Evaluation of symbiotic properties Green house experiments}

All the GMR were authenticated and tested for their symbiotic effectiveness on a soybean cultivar (Ethio-Yugoslavia) used for their trapping. Two more effective GMR (GMR120C and GMR125B) were selected and evaluated on two other soybean cultivars, locally called Jalele and Cheri (Bako Agricultural Research Center, western Ethiopia). A Bradyrhizobium japonicum TAL379, which had been commonly used in field experiments in the country, was included as reference in green house and field experiments.

Soybean seeds were surface sterilized as mentioned earlier, pre-germinated on $1.5 \%(\mathrm{w} / \mathrm{v})$ water-agar plates and three seedlings were transplanted into sterile potted river sand $\left(3 \mathrm{~kg} \mathrm{pot}^{-1}\right)$. Each seedling was pipetted 
at its base with $1 \mathrm{~mL} \log$ phase YMB culture $\left(\approx-10^{8}\right.$ cells, $\left.0.91 \mathrm{OD}^{540}\right)$. $\mathrm{N}$-fertilized $\left(0.05 \% \mathrm{KNO}_{3}\right.$ every week) and un-inoculated (non-nitrogen fertilized) pots were included as positive and negative control, respectively. All pots were watered (distilled $\mathrm{H}_{2} \mathrm{O}$ ) as required and weekly supplied with quarter strength $\mathrm{N}$-free nutrient solution for grain legumes (Broughton and Dilworth 1970). Treatments were done in triplicate and arranged in a randomized complete block design in a greenhouse (12 h photoperiod; $27 \pm 2{ }^{\circ} \mathrm{C} / 17 \pm 3{ }^{\circ} \mathrm{C}$ day/night temperature) for 60 days. Plants were uprooted followed by nodule collection and enumeration. Shoots and nodules were dried at $70{ }^{\circ} \mathrm{C}$ for $48 \mathrm{~h}$ for dry weight determination (Somasegaran and Hoben 1994). Shoot total nitrogen was determined following Kjeldahl method and the symbiotic effectiveness (SE) of the GMR was calculated according to Purchino et al. (2000).

\section{Field experiment}

Symbiotic performance of GMR120C and GMR125B was also evaluated under rain fed field conditions. A soybean rhizosphere PGP Achromobacter sp. SR20A (Temesgen et al. 2019) was included for co-inoculation tests. An early maturing soybean cultivar (Jalele), which also showed well nodulation and growth under greenhouse conditions, was selected principally due to inconsistency in the duration of rainy season. Early maturing soybean varieties have short growing season and suitable for moisture stressed agro ecology of Ethiopia (Deresse 2019).

Field experiments were conducted at two agricultural research centers (ARC): Bako ARC and Dembi Station of Debrezeit ARC during the main cropping seasons (June to October). Dembi station of Debrezeit ARC is located at $8^{\circ} 44^{\prime} \mathrm{N}, 38^{\circ} 55^{\prime} \mathrm{E}$ and at 1930 masl in East Shoa Zone of Oromia Regional State, central Ethiopia. The average rainfall during the cropping seasons was 61, 161, 215, 101 and $9.7 \mathrm{~mm}$ for June, July, August, September and October, respectively. The mean monthly temperature varied from $16{ }^{\circ} \mathrm{C}$ (October) to $20{ }^{\circ} \mathrm{C}$ (June). The soil temperature of the area (determined at 5, 10 and $20 \mathrm{~cm}$ depth) was varied between 22 and $30^{\circ} \mathrm{C}$. Bako ARC is located at $09^{\circ} 06^{\prime} \mathrm{N}, 37^{\circ} 09^{\prime} \mathrm{E}$ and at 1650 masl in West Shoa Zone of Oromia Regional State. The average rainfall during the cropping seasons was 260.1, 222.4, 135.3, 136.5 and $71.3 \mathrm{~mm}$ for June, July, August, September and October, respectively. The mean monthly temperature was within the range of $19.6{ }^{\circ} \mathrm{C}$ (August) to $21.1{ }^{\circ} \mathrm{C}$ (October). The soil temperature of the area (determined at the above mentioned depths) was varied from 23 to $25.1{ }^{\circ} \mathrm{C}$. Climatic data of the field sites were obtained from their respective research centers. The most probable number (MPN) of indigenous soybean rhizobia (determined by plant infection method according to Somasegaran and Hoben (1994) and the properties of composite soil samples of the field sites (determined at Nekemte Soil Laboratory and Testing Center, Western Ethiopia, following standard methods) are shown in Table 1.

GMR120C, GMR125B and the reference B. japonicum were grown to late $\log$ phase $\left(72 \mathrm{~h} ; 10^{9}\right.$ cells $\mathrm{mL}^{-1}$ YMB) and applied to surface sterilized seeds in two step method according to Singleton et al. (1990). For co-inoculation, cultures of each GMR (and reference strain) and the rhizobacterium $\left(\mathrm{SR} 20 \mathrm{~A} ; \approx 10^{9}\right.$ cells $\mathrm{mL}^{-1}$ nutrient broth) were mixed in a 1:1 (v/v) ratio according to Yadav et al. (2011) prior to mixing with peat, a carrier.

There were 8 treatments: three separate rhizobia inoculations (GMR120C, GMR125B and TAL379), these three rhizobia each co-inoculated with SR20A, a urea applied control and a control without any input. Treatments were designed in a randomized complete block design with three replications. Urea (for $\mathrm{N}$-supplied plots) and trisuperphosphate, $\mathrm{P}_{2} \mathrm{O}_{5}$ (to all plots) were applied to the soil at the rate of $46 \mathrm{~kg} \mathrm{ha}^{-1}$ as recommended by conventional farmers' fertilizer recommendation level before sowing according to Argaw (2012).

Seeds were sown $10 \mathrm{~cm}$ apart from each other in a row ( 8 rows per plot; $40 \mathrm{~cm}$ between successive rows) at $4 \mathrm{~cm}$ depth on June 24 at Bako ARC, but on July 17 at Dembi station of Debrezeit ARC. Seed sowing delay at the latter was due to delay in the beginning of rain though it should be sown in June as at Bako ARC where rain started at the usually time. Sixty days after planting (60 DAP), ten plants were randomly uprooted from the third border rows of each plot to count nodules, measure shoot height and determine shoot and nodule dry weights. Shoot nitrogen content was determined using Kjeldahl method

Table 1 MPN of indigenous soybean rhizobial and some properties of soils of the experimental sites

\begin{tabular}{|c|c|c|c|c|c|c|c|c|c|c|}
\hline \multirow[t]{2}{*}{ Field site } & \multirow[t]{2}{*}{$\mathrm{pH} 1: 2.5$} & \multirow[t]{2}{*}{ OC\% } & \multirow[t]{2}{*}{ TN\% } & \multirow[t]{2}{*}{$\mathrm{AP}(\mathrm{ppm})$} & \multirow[t]{2}{*}{ OM\% } & \multicolumn{3}{|c|}{ Particle size \% } & \multirow[t]{2}{*}{ Texture } & \multirow[t]{2}{*}{ MPN } \\
\hline & & & & & & Sand & Silt & Clay & & \\
\hline BARC & 5.02 & 2.17 & 0.175 & 12.85 & 4.21 & 47 & 33 & 30 & Sand clay loam & $6.3 \times 10^{3}$ \\
\hline DDARC & 6.15 & 3.63 & 0.313 & 31.85 & 6.26 & 27 & 47 & 26 & Loam soil & $2.2 \times 10^{1}$ \\
\hline
\end{tabular}

$O C$ organic carbon, $T N$ total nitrogen, $A P$ available phosphate, $p p m$ parts per million, $O M$ organic matter, $M P N$ most probable number; $\mathrm{pH} 1: 2.5=\mathrm{pH}$ determined by 1:2.5 Soil: $\mathrm{H}_{2} \mathrm{O}$ ratio method; Values of soil properties are means of three replicates 
(Sertsu and Bekele 2000). At physiological maturity, ten other plants were randomly collected from the two central rows of each plot to determine the number of pods per plant, number of seeds per pod and per plant, grain yield and weight of 1000 seeds at $10 \%$ seed moisture (Grain Moisture Meter Draminski ${ }^{\circledR}$, Poland).

\section{Data analysis}

Data were assessed by analysis of variance (ANOVA) employing SAS computer software package version 9.3 (SAS 2000-2004). Mean separations were undertaken using the Duncan's Multiple Range Test at $p \leq 0.05$. All quantitative data sets were tested for normality using Kolmogorov Simirnov test and for variance homogeneity by Bartlett's test before being pooled for combined ANOVA (Gomez and Gomez 1984). Phenotypic variability of the test rhizobia (GMR and TAL379) was analyzed using multivariate classical cluster analysis and a paired group (UPGMA) algorithm phenotypic dendrogram with Jaccard similarity index was constructed employing PAST4.03 Computer Software based on 79 phenotypic traits.

\section{Result}

\section{Cultural characteristics of GMR}

Twelve GMR that were recovered from nodulated plants showed generation time (g) and colony diameter varying from 1.5 to $6.6 \mathrm{~h}$ and from 2.5 to $6 \mathrm{~mm}$, respectively (Table 2). Ten of the GMR displayed fast generation rate $(1.5-4 \mathrm{~h})$ with larger colony diameter $(3-6 \mathrm{~mm})$ and the remaining two GMR showed slower generation time (5.5-6.6 h) with smaller colony diameter $(2.5$ or $3 \mathrm{~mm}$ ).
GMR with fast and slow generation time turned BTBYMA medium into yellow and blue, respectively. Most of the GMR produced circular-gummy colonies with entire margin (CGE) except a slow growing GMR (GMR75) and two fast growing GMR (GMR120C and GMR125B) which formed filamentous-dry(less gummy) colonies with irregular margin (FDI). Three Sinorhizobium spp. (GMR55, GMR102 and GMR114) and the reference TAL 379 showed shinny translucent colonies with entire margin.

\section{Tolerance against stresses}

Most fast growing GMR tolerated 4 to $6 \% \mathrm{NaCl}$ whereas slow growing GMR tolerated $\leq 1.5 \% \mathrm{NaCl}$ (Table 3). None of the GMR could grow at $\mathrm{pH}$ lower than 5, but they all managed to grow at $\mathrm{pH} 9.5$. Most of the GMR were able to grow at $40{ }^{\circ} \mathrm{C}$. GMR were also varied in their intrinsic resistance against antibiotics, heavy metals and agrochemicals (Table 3). GMR13, GMR120B, GMR120C and GMR125B combined higher salt $(6 \% \mathrm{NaCl})$ and higher temperature $\left(40-45{ }^{\circ} \mathrm{C}\right.$.) tolerance traits. Ampicillin $\left(200 \mu \mathrm{g} \mathrm{mL}^{-1}\right)$, Chloramphenicol $\left(25 \mu \mathrm{g} \mathrm{mL} \mathrm{m}^{-1}\right)$, Penicillin $\mathrm{G}\left(200 \mu \mathrm{g} \mathrm{mL}^{-1}\right)$ and Tetracycline $\left(10 \mu \mathrm{g} \mathrm{mL}^{-1}\right)$ were resisted by at least $50 \%$ of the GMR. However, none of the GMR grew when exposed to Erythromycin $\left(100 \mu \mathrm{g} \mathrm{mL}^{-1}\right)$. Similarly, $75 \%$ of the GMR were sensitive to Gentamycin $\left(20 \mu \mathrm{g} \mathrm{mL}^{-1}\right)$, Streptomycin sulfate $\left(10 \mu \mathrm{g} \mathrm{mL}^{-1}\right)$ and Cifroflaxin $\left(10 \mu \mathrm{g} \mathrm{mL} \mathrm{m}^{-1}\right)$. GMR13 was sensitive to all the tested antibiotics followed by GMR55 and GMR79 that showed sensitivity against $90 \%$ and $80 \%$ of the antibiotics. On the contrary, GMR120B resisted $80 \%$ of the tested antibiotics. Similarly, all the GMR and

Table 2 Genus, colony features, acid/alkali production and generation time (g) of the GMR (Glycine max rhizobia)

\begin{tabular}{|c|c|c|c|c|c|c|}
\hline \multirow[t]{2}{*}{ Sr.No } & \multirow[t]{2}{*}{ GMR code } & \multirow[t]{2}{*}{ Suggested genus } & \multicolumn{2}{|c|}{ Colony characteristics } & \multirow[t]{2}{*}{ BTB reaction } & \multirow[t]{2}{*}{ Mean g (h) } \\
\hline & & & Size $(\mathrm{mm})$ & $\begin{array}{l}\text { Colony texture } \\
\text { and shape }{ }^{1}\end{array}$ & & \\
\hline 1 & GMR 13 & Sinorhizobium & 5 & CGE & Yellow & 2.0 \\
\hline 2 & GMR45 & Sinorhizobium & 6 & CGE & Yellow & 1.5 \\
\hline 3 & GMR46 & Bradyrhizobium & 2.5 & CGE & Blue & 5.5 \\
\hline 4 & GMR55 & Sinorhizobium & 3 & $C G(S) E$ & Yellow & 3.2 \\
\hline 5 & GMR57 & Sinorhizobium & 3 & CGE & Yellow & 3.7 \\
\hline 6 & GMR75 & Bradyrhizobium & 3 & FDI & blue & 6.6 \\
\hline 7 & GMR79 & Sinorhizobium & 4 & CGE & Yellow & 3.3 \\
\hline 8 & GMR102 & Sinorhizobium & 4 & $C G(S) E$ & Yellow & 3.6 \\
\hline 9 & GMR114 & Sinorhizobium & 5 & $C G(S) E$ & Yellow & 3.8 \\
\hline 10 & GMR120B & Sinorhizobium & 5 & CGE & Yellow & 4.0 \\
\hline 11 & GMR120C & Sinorhizobium & 3 & FDI & Yellow & 3.6 \\
\hline 12 & GMR125B & Sinorhizobium & 6 & FDI & Yellow & 3.5 \\
\hline
\end{tabular}

$1=$ circular-gummy colonies with entire margin, $\mathrm{CG}(\mathrm{S}) \mathrm{E}=$ circular-gummy (shinny colonies) with entire margin; FDI: Filamentous, dry (less gummy) colonies with irregular margin 
Table 3 Tolerances of the GMR and the reference B. japonicum (TAL379) against various stresses

\begin{tabular}{|c|c|c|c|c|c|c|c|c|c|c|c|c|c|}
\hline \multirow[t]{2}{*}{ Stress } & \multicolumn{10}{|c|}{ Fast growing } & \multicolumn{3}{|c|}{ Slow growing } \\
\hline & $\begin{array}{l}\text { GMR } \\
13\end{array}$ & $\begin{array}{l}\text { GMR } \\
45\end{array}$ & $\begin{array}{l}\text { GMR } \\
55\end{array}$ & $\begin{array}{l}\text { GMR } \\
57\end{array}$ & $\begin{array}{l}\text { GMR } \\
79\end{array}$ & $\begin{array}{l}\text { GMR } \\
102\end{array}$ & $\begin{array}{l}\text { GMR } \\
114\end{array}$ & $\begin{array}{l}\text { GMR } \\
120 B\end{array}$ & $\begin{array}{l}\text { GMR } \\
120 C\end{array}$ & $\begin{array}{l}\text { GMR } \\
125 B\end{array}$ & $\begin{array}{l}\text { GMR } \\
46\end{array}$ & $\begin{array}{l}\text { GMR } \\
75\end{array}$ & $\begin{array}{l}\text { TAL } \\
379\end{array}$ \\
\hline$\% \mathrm{NaCl}^{*}(\mathrm{w} / \mathrm{v})$ & 6 & 5 & 4 & 2 & 4 & 4 & 1.5 & 6 & 6 & 6 & 0.5 & 1.5 & 3 \\
\hline${ }^{1}$ Temperature $\left({ }^{\circ} \mathrm{C}\right)$ & 45 & 37 & 40 & 40 & 40 & 40 & 40 & 40 & 45 & 40 & 37 & 40 & 37 \\
\hline${ }^{2} \mathrm{pH}$ & 5.5 & 5 & 5.5 & 5 & 5 & 5 & 5 & 5 & 5 & 5.5 & 5.5 & 5.5 & 5 \\
\hline \multicolumn{14}{|l|}{ Antibiotics $\left(\mu \mathrm{g} \mathrm{mL}^{-1}\right)$} \\
\hline Ampicillin (200) & - & + & - & + & - & - & + & + & + & + & - & + & + \\
\hline Chloramphenicol (25) & - & + & - & + & - & - & + & + & + & + & + & + & + \\
\hline Gentamycin (20) & - & - & - & - & - & - & - & + & - & + & + & - & + \\
\hline Naldixic acid (100) & - & + & - & - & - & - & - & + & + & - & + & - & + \\
\hline Penicillin G (200) & - & + & + & + & + & + & + & + & + & + & + & + & + \\
\hline Streptomycin—sulfate (10) & - & + & - & - & - & + & - & + & - & - & - & - & + \\
\hline Tetracycline (10) & - & - & - & - & - & + & - & + & + & + & + & + & - \\
\hline Vancomycin (15) & - & + & - & + & + & - & - & + & + & + & + & - & + \\
\hline Erythromycine (100) & - & - & - & - & - & - & - & - & - & - & - & - & - \\
\hline Cifroflaxin (10) & - & - & - & - & - & - & - & - & + & + & + & - & - \\
\hline \multicolumn{14}{|l|}{ Heavy metals (mM) } \\
\hline $\mathrm{CoCl}_{2} \cdot 6 \mathrm{H}_{2} \mathrm{O}(0.5)$ & - & + & + & + & + & + & + & + & + & + & + & + & - \\
\hline $\mathrm{K}_{2} \mathrm{Cr}_{2} \mathrm{O}_{7}(0.25)$ & + & - & - & - & - & - & - & - & + & + & - & - & - \\
\hline $\mathrm{CuCl}_{2} \cdot 2 \mathrm{H} 2 \mathrm{O}(0.25)$ & - & - & - & + & - & - & - & - & + & - & - & - & - \\
\hline \multicolumn{14}{|l|}{ Agrochemicals } \\
\hline Mancozeb $\left(2 \mathrm{~g} \mathrm{~L}^{-1}\right)$ & + & - & + & - & - & - & - & - & + & + & - & - & - \\
\hline Curzet $\left(2 \mathrm{~g} \mathrm{~L}^{-1}\right)$ & - & - & - & - & - & - & - & - & - & - & - & - & - \\
\hline Glyphosate (1444 $\left.\mu \mathrm{g} \mathrm{mL} \mathrm{m}^{1}\right)$ & - & - & + & + & + & + & - & + & + & + & - & - & - \\
\hline
\end{tabular}

1 represents highest growth values; 2 represents lowest growth value; "+" stands for the presence of growth and "-" stands for the absence of growth in response to the stresses

the reference B. japonicum resisted $\mathrm{ZnSO}_{4} \cdot 7 \mathrm{H}_{2} \mathrm{O}$ and $\mathrm{MnSO}_{4} \cdot \mathrm{H}_{2} \mathrm{O}(0.25 \mathrm{mM}$ each $)$ and $\mathrm{Pb}\left(\mathrm{CH}_{3} \mathrm{COO}\right)_{2} \cdot 3 \mathrm{H}_{2} \mathrm{O}$ (2.5 mM) (data not shown). However, $\mathrm{CuCl}_{2} \cdot 2 \mathrm{H}_{2} \mathrm{O}$ and $\mathrm{K}_{2} \mathrm{Cr}_{2} \mathrm{O}_{7}(0.25 \mathrm{mM}$ each) inhibited the growth of $83 \%$ and $75 \%$ of the GMR, respectively. With regard to specific GMR, GMR120C resisted all tested heavy metals followed by GMR 57 and GMR125B that resisted $83 \%$ of the evaluated heavy metals. All the remaining GMR resisted $67 \%$ of the tested heavy metals. Mancozeb $\left(2 \mathrm{~g} \mathrm{~L}^{-1}\right)$ and curzet $\left(2 \mathrm{~g} \mathrm{~L}^{-1}\right)$ inhibited the growth of 67 and $100 \%$ of the GMR, respectively. Glyphosate $(0.14 \%)$ also inhibited the growth of $42 \%$ of the GMR. The reference B. japonicum was sensitive to all the agrochemicals similar to GMR45, GMR46, GMR75 and GMR114.

\section{Utilization of carbon and nitrogen substrates}

Six fast growing GMR (GMR13, GMR45, GMR120B, GMR120C and GMR125B) were able to utilized the entire tested carbon sources (19) and nitrogen sources (12) (Fig. 2).Three other fast growing GMR (GMR55, GMR57 and GMR114) and a slow growing GMR (GMR75) were also able to utilize all the tested nitrogen

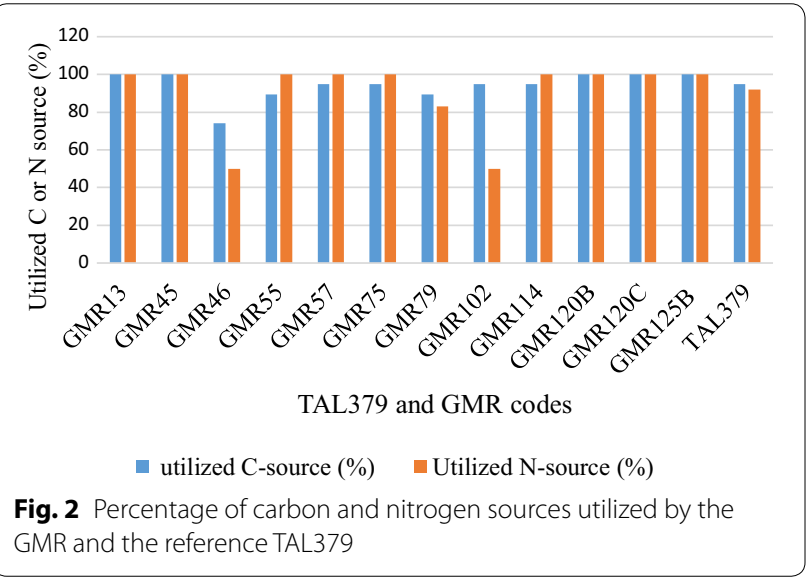

sources. However, a slow growing GMR (GMR46) utilized the least percentage of carbon source (74\%). It also utilized the least percentage of nitrogen sources $(50 \%)$ together with a fast growing GMR102. Na-citrate and lysine were the carbon and nitrogen sources, respectively, that were utilized relatively by less number of bacteria 
than the other carbon or nitrogen sources. The reference B. japonicum (TAL379) utilized over $90 \%$ of the carbon and nitrogen sources.

\section{Plant growth promoting (PGP) traits}

All the GMR and the reference B. japonicum produced IAA which significantly varied $(\mathrm{p} \leq 0.05)$ from $2.5 \mu \mathrm{M}$ for GMR46 (Bradyrhizobium) to $116 \mu \mathrm{M}$ for GMR45 (Sinorhizobium) (Fig. 3). Twenty five percent of the GMR

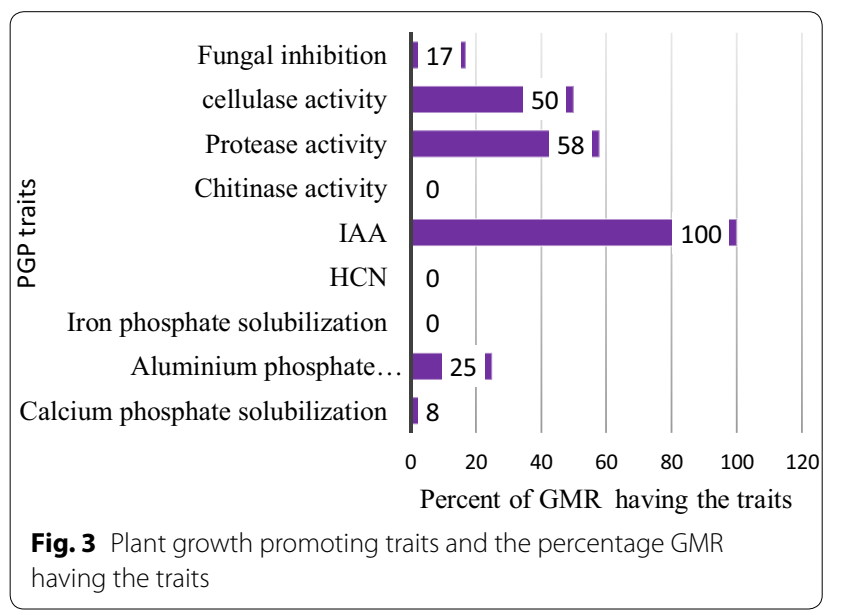

solubilized aluminium phosphate (SI: 1.4-1.6) with no significant variation $(\mathrm{p} \leq 0.05)$ whereas tri-calcium phosphate was solubilized by GMR13 alone $(\mathrm{SI}=1.5)$. Fifty eight and fifty percent of the GMR showed protease and cellulase activity, respectively. Two (17\%) of the GMR; GMR79 and GMR102 showed anti-Fusarium oxysporum activity with $33 \%$ and $17 \%$ inhibition of radial growth (PIRG), respectively. However, no GMR showed ironphosphate $\left(\mathrm{FePO}_{4}\right)$ solubilization, chitinase and $\mathrm{HCN}$ production activities (Fig. 3 ). The reference $B$. japonicum (TAL379) solubilized aluminium phosphate with SI of 1.4 and recorded a lower level of IAA $(10.23 \mu \mathrm{M})$.

\section{Phenotypic variability}

In the dendrogram constructed based on phenotypic similarities of the GMR plus TAL379, a Bradyrhizobium sp. (GMR46) was separated from the rest at about $57 \%$ level of similarity (Fig. 4). GMR46 was distinguished from the rest bacteria mainly due to its ability to utilize narrower range of substrates and its sensitivity against salt and pesticides. The remaining rhizobia were separated into a major cluster (GMR13 and two sub clusters [II and III]) and a minor cluster (I) at 75\% similarity level. Cluster I consisted two Sinorhizobium spp. (GMR57 and GMR114) and a Bradyrhizobium sp. (GMR75). Members this cluster were characterized

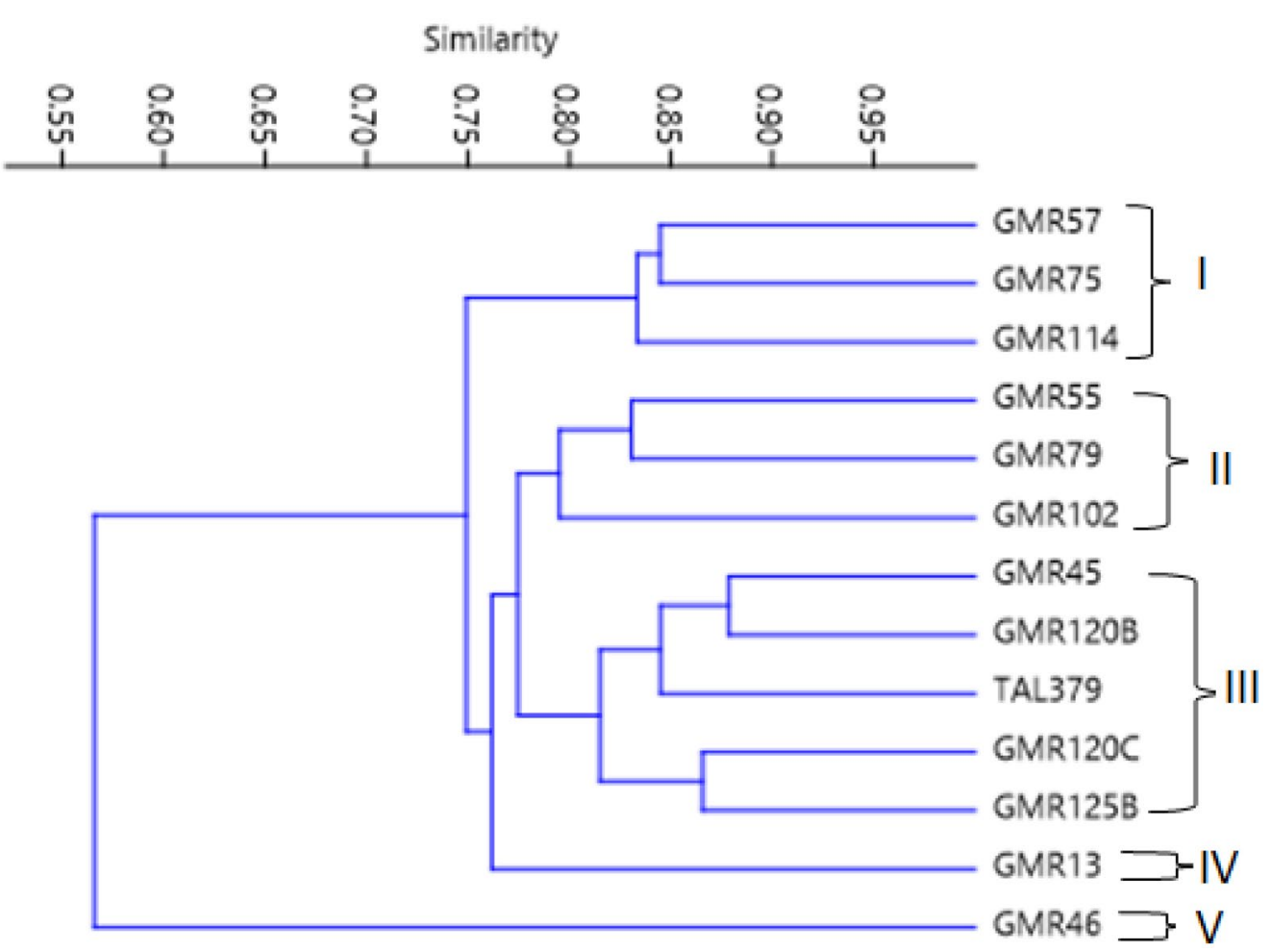

Fig. 4 Dendrogram highlighting phenotypic similarity of the GMR and reference TAL379 
by efficient utilization of substrates and with relatively higher antibiotic sensitivity and resistance against heavy metals. Cluster II comprised three Sinorhizobium spp. (MRR55, GMR79 and GMR102) which were characterized by antibiotic sensitivity and tolerance against higher salt concentration and heat level traits. Cluster III consisted four Sinorhizobium spp. and TAL379 which shared features like utilization of wide range of substrates and relatively good tolerance against antibiotics and higher salt concentration. Symbiotic effective Sinorhizobium spp (GMR120C and GMR125B) were also included in cluster III and separated from each other at about $87 \%$ similarity level. The test rhizobia formed no cluster beyond about $88 \%$ similarity level. GMR13 was separated from all the test bacteria at about $76 \%$ similarity level and it was unique in being sensitivity to all the tested antibiotics.

\section{Symbiotic properties \\ Green house experiments}

Plants inoculated with GMR120C and GMR125B showed good growth with greener leaves (Fig. 5). On the other hand, TAL379 inoculated or negative control plants showed stunted growth with yellowish leaves. The positive control (N-fertilized) plants showed medium growth and in the greenness of their leaves.

The nodule number and dry weight $(\mathrm{mg})$ induced by GMR ranged from 2 to 106 and from 17 to 201 plant $^{-1}$, respectively with statistically significant variation at $\mathrm{p} \leq 0.05$ (Table 4). The minimum nodule number
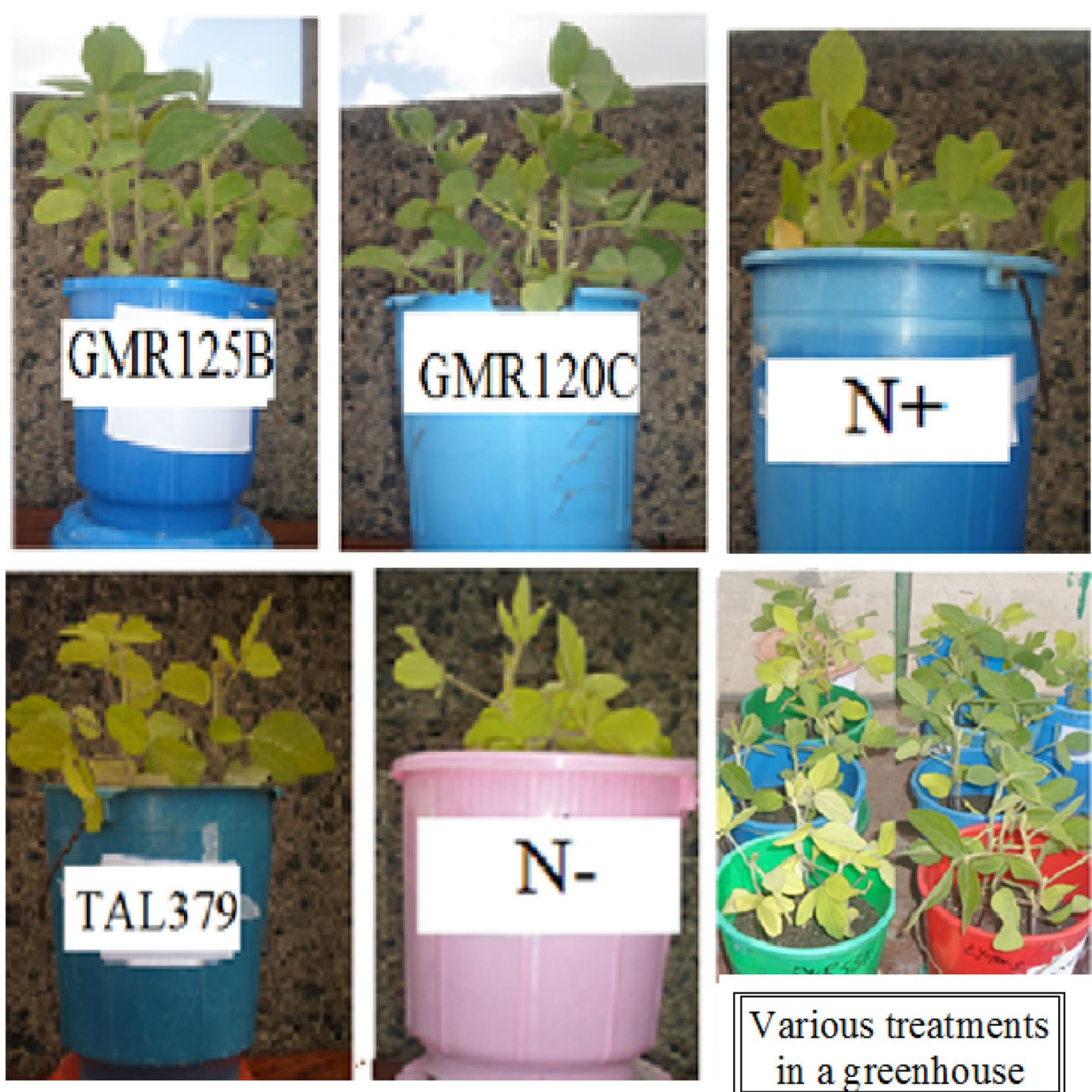

Fig. 5 Growth and appearance of plants resulting from different treatments (separated or together [the last figure]) in the greenhouse experiments 
Table 4 Greenhouse inoculation effects of the GMR and TAL379 on the three cultivars of soybean

\begin{tabular}{|c|c|c|c|c|c|c|c|}
\hline Cultivar & Treatment & NN & NDW (mg) & $\mathrm{SL}(\mathrm{cm})$ & TN\% & SDW (g) & SE (\%) \\
\hline \multirow[t]{14}{*}{ Ethio-Yugslovia } & GMR13 & $10^{c}$ & $50^{b c}$ & $18^{a b c}$ & $1.7^{\mathrm{b}}$ & $0.8^{c}$ & $60.24^{b c}$ \\
\hline & GMR46 & $15^{c}$ & $31^{e}$ & $17^{a b c}$ & $1.8^{\mathrm{b}}$ & $0.9^{c}$ & $64.88^{\mathrm{bc}}$ \\
\hline & GMR55 & $2^{c}$ & $27^{e}$ & $19^{a b c}$ & $1.9^{b}$ & $1.1^{b c}$ & $82.92^{\mathrm{ab}}$ \\
\hline & GMR57 & $3^{c}$ & $75^{\mathrm{ab}}$ & $18^{a b c}$ & $1.8^{b}$ & $1.1^{\mathrm{bc}}$ & $78.05^{\mathrm{ab}}$ \\
\hline & GMR75 & $2.3^{c}$ & $40^{c d}$ & $16^{\mathrm{cd}}$ & $2.9^{\mathrm{a}}$ & $0.8^{c}$ & $58.54^{\mathrm{bc}}$ \\
\hline & GMR79 & $2^{c}$ & $17^{e}$ & $20^{a b c}$ & $1.6^{\mathrm{b}}$ & $1.3^{b c}$ & $97.56^{\mathrm{a}}$ \\
\hline & GMR102 & $3.0^{c}$ & $29^{e}$ & $16^{\mathrm{abc}}$ & $1.9^{b}$ & $1.2^{\mathrm{bc}}$ & $90.24^{\mathrm{a}}$ \\
\hline & GMR114 & $14^{c}$ & $23^{e}$ & $14^{\mathrm{cd}}$ & $1.9^{b}$ & $0.8^{c}$ & $61.22^{\mathrm{bc}}$ \\
\hline & GMR120B & $3^{c}$ & $36^{e}$ & $20^{a b c}$ & $1.9^{b}$ & $1.2^{\mathrm{bc}}$ & $100.00^{\mathrm{a}}$ \\
\hline & GMR120C & $103^{\mathrm{a}}$ & $61^{\mathrm{ab}}$ & $20^{a b c}$ & $3.3^{\mathrm{a}}$ & $1.4^{\mathrm{bc}}$ & $104.63^{\mathrm{a}}$ \\
\hline & GMR125B & $70^{b}$ & $87^{a b}$ & $21^{\mathrm{ab}}$ & $3.2^{\mathrm{a}}$ & $1.4^{\mathrm{bc}}$ & $100.00^{\mathrm{a}}$ \\
\hline & TAL379 & $2^{c}$ & $29^{e}$ & $17^{a b c}$ & $1.7^{b}$ & $0.5^{c}$ & $39.02^{c}$ \\
\hline & $\mathrm{N}+$ & $0^{c}$ & $0^{f}$ & $21^{\mathrm{ab}}$ & $2.8^{\mathrm{a}}$ & $1.4^{\mathrm{bc}}$ & $100.0^{\mathrm{a}}$ \\
\hline & $\mathrm{N}-$ & $0^{c}$ & $0^{f}$ & $19^{a b}$ & $1.4^{\mathrm{b}}$ & $0.6^{c}$ & $41.46^{b c}$ \\
\hline \multirow[t]{5}{*}{ Cheri } & GMR120C & $80^{\mathrm{a}}$ & $110^{b}$ & $17^{a b c}$ & $3.14^{\mathrm{a}}$ & $1.8^{\mathrm{b}}$ & $139.5^{\mathrm{a}}$ \\
\hline & GMR125B & $94^{a}$ & $201^{a}$ & $22^{\mathrm{ab}}$ & $3.27^{\mathrm{a}}$ & $2.0^{\mathrm{a}}$ & $160.52^{\mathrm{a}}$ \\
\hline & TAL379 & $2.3^{b}$ & $46^{c}$ & $20^{\mathrm{ab}}$ & $1.67^{b}$ & $0.6^{c}$ & $44.90^{c}$ \\
\hline & $\mathrm{N}+$ & $0^{c}$ & $0^{d}$ & $17^{\mathrm{abc}}$ & $2.93^{\mathrm{a}}$ & $1.3^{b c}$ & $100.0^{\mathrm{abc}}$ \\
\hline & $\mathrm{N}-$ & $0^{c}$ & $0^{d}$ & $12^{\mathrm{d}}$ & $1.40^{b}$ & $0.8^{c}$ & $57.89^{b c}$ \\
\hline \multirow[t]{5}{*}{ Jalele } & GMR120C & $89^{a}$ & $146^{\mathrm{a}}$ & $27.0^{\mathrm{a}}$ & $3.30^{\mathrm{a}}$ & $2.3^{\mathrm{a}}$ & $170.0^{\mathrm{a}}$ \\
\hline & GMR125B & $106^{a}$ & $130^{\mathrm{a}}$ & $25.3^{\mathrm{a}}$ & $3.33^{\mathrm{a}}$ & $2.1^{\mathrm{a}}$ & $160.0^{\mathrm{ab}}$ \\
\hline & TAL379 & $2^{c}$ & $44^{b}$ & $20^{a b c}$ & $1.63^{b}$ & $1.1^{b c}$ & $85.0^{\mathrm{cd}}$ \\
\hline & $\mathrm{N}+$ & $0^{c}$ & $0^{c}$ & $21^{\mathrm{ab}}$ & $2.87^{a}$ & $1.3^{b c}$ & $100.0^{c d}$ \\
\hline & $\mathrm{N}-$ & $0^{c}$ & $0^{c}$ & $18^{\mathrm{abc}}$ & $1.43^{b}$ & $0.9^{c}$ & $70.0^{d}$ \\
\hline
\end{tabular}

NN nodule number, NDW nodule dry weight, SL shoot length, SDW shoot dry weight, SE symbiotic effectiveness. Numbers raised to different letters are significantly different (at $\mathrm{p} \leq \mathrm{0.05}$ ) for each cultivar (Comparisons were made within columns among inoculants for each cultivar)

and nodule dry weight was recorded for GMR79. Two Sinorhizobium spp. (GMR120C and GMR125B) induced higher number of nodules associated with higher nodule dry weight, shoot total nitrogen percent and symbiotic effectiveness than the other GMR and the reference TAL379 on all the three cultivars of the crop. The accumulated shoot total nitrogen percent of these Sinorhizobium spp. inoculated plants was in the range of 3.14 to 3.33 whereas their symbiotic effectiveness was in the range of 100 to $170 \%$ on the three soybean cultivars. The symbiotic effectiveness was higher on cultivar Jalele and Cheri than Ethio-Yugslovia. The Sinorhizobium spp also improved shoot height over uninoculated negative control plants though the differences were not statistically significant among all treatments $(p \leq 0.05)$. On the contrary, the other GMR and the reference $B$. japonicum showed poor nodulation (nodule number: 2 to 14 ) with symbiotic performance ranging from 58.5 to $100 \%$ on the three cultivars of soybean (Table 4). As expected, un-inoculated control plants produced no nodules.

\section{Field experiments}

Nodulation and growth responses of soybean GMR120C and GMR125 inoculated plants produced abundant nodules with pinkish interior (Fig. 6b) grew well with greener leaves and more branches (Fig. 6a). Positive and negative control plants showed relatively poor growth with yellower leaves (Fig. 6c, e). Similarly TAL379 inoculated plants showed less growth with fewer small and white nodules (Fig. 6d; white arrows).

Inoculation of the two selected Sinorhizobium spp. (GMR120C and GMR125B) singly or dually with the plant growth promoting Achromobacter sp. (SR20A) induced significantly higher nodule number than control treatments and reference B. japonicum at Dembi station of Debrezeit ARC (Table 5). At Bako ARC field site, only un-inoculated and $\mathrm{N}$-fertilized unsupplied control plants and GMR120C-SR20A co-inoculated plants produced significantly different or higher nodule number among the treatments. The nodule number and nodule dry weight of GMR inoculated plants was in the range of $32-132$ and $0.45-1.67$ (g plant ${ }^{-1}$ ), respectively. The 


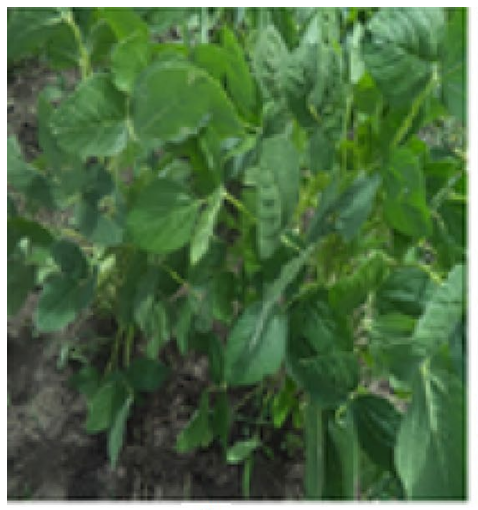

a

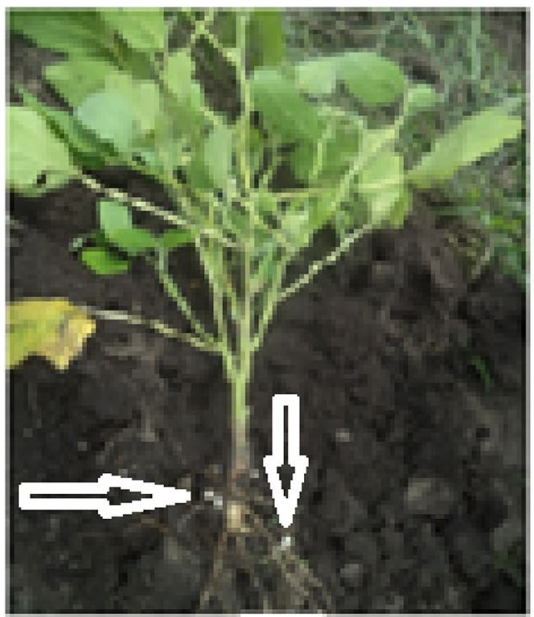

d

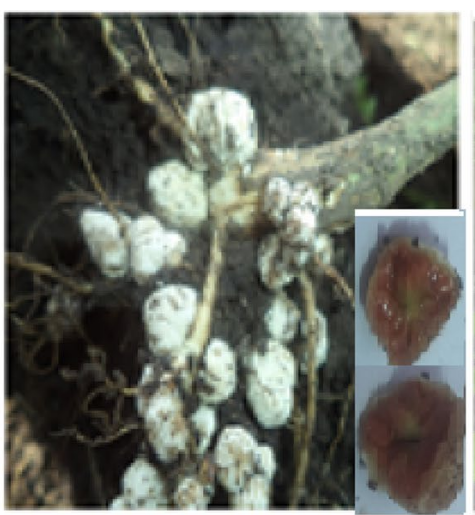

b

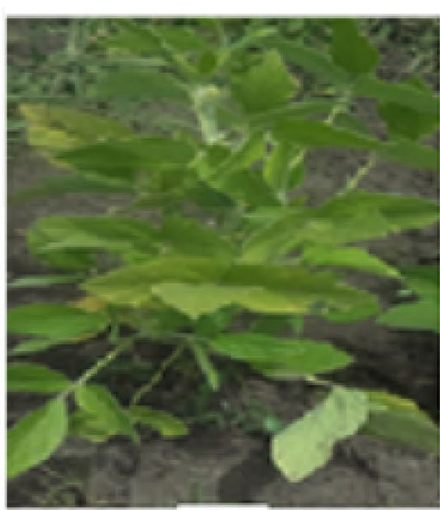

c

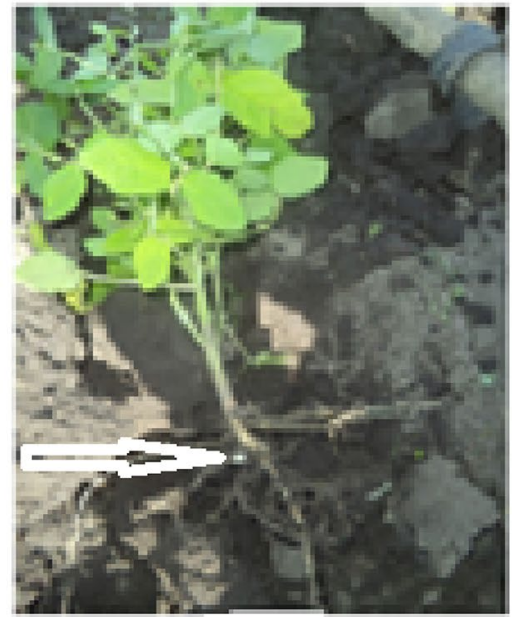

e

Fig. 6 Appearance of selected GMR inoculated plants (a) and their nodules including interior sections (b), N-supplied plants (c), uprooted plants inoculated with TAL379 (d) and uprooted negative control plants (e) under field condition. The white arrows pointed towards small white nodules

maximum nodule number associated with maximum nodule dry weight was recorded for plants co-inoculated with GMR125B and SR20A. At both field sites, N-fertilized plants produced the least number of nodules. Variations were also recorded in shoot height, total nitrogen percent and dry weight among the treatments at both field sites, but the variations were statistically significant $(p \leq 0.05)$ only in few cases though shoot total nitrogen percent was consistently higher for GMR inoculations. The exotic B. japonicum TAL379 showed poor nodulation as revealed under field condition with fewer MPN background soybean rhizobia. Under such field site, TAL379 also accumulated lower shoot total nitrogen percent and shoot dry weight than GMR inoculated singly or dually with the PGP Achromobacter sp.

Yield and yield related responses of soybean GMR inoculated plants produced higher number of pods per plant
(51 to 102) but lower number of seeds per pod (1.64 to 2.08) at Dembi station of Debrezeit ARC compared to Bako ARC field site with 37 to 44 pods plant $^{-1}$ and 2.07 to 2.08 seeds pod ${ }^{-1}$. (Table 6 ). However, the mean number of seeds per plant (NSPPL) was higher at Dembi station of Debrezeit ARC corresponding to the higher number of pods per plant (NPP). The maximum number of pods plant $^{-1}$ was recorded for GMR120C inoculated plants at Dembi station of Debrezeit ARC field site. But, the maximum number of seeds pod ${ }^{-1}$ and number of seeds plant ${ }^{-1}$ was recorded for GMR125 inoculated plants at Bako ARC field site and for GMR125B-SR20A co-inoculated plants at Dembi station of Debrezeit ARC field site, respectively. Grain yield for GMR120C and GMR125B inoculation was varied from 3.16 to 3.98 tons $\mathrm{ha}^{-1}$ at the field sites. Single GMR120C inoculation resulted in higher grain yield (3.81-3.97 tons $\left.\mathrm{ha}^{-1}\right)$ than its co-inoculation with SR20A (3.35-3.51 tons $\mathrm{ha}^{-1}$ ) at both field sites. On the contrary, 
Table 5 Effects of different treatments on nodulation and growth of soybean at the two field sites

\begin{tabular}{llllll}
\hline Treatment & NN & NDW (g) & SH (cm) & TN\% & SDW (g) \\
\hline Bako ARC field site & & & & & \\
GMR120C & $46.11^{\mathrm{bc}}$ & $0.45^{\mathrm{a}}$ & $34.13^{\mathrm{a}}$ & $3.57^{\mathrm{a}}$ & $15.6^{\mathrm{abc}}$ \\
GMR125B & $46.22^{\mathrm{bc}}$ & $0.63^{\mathrm{a}}$ & $38.56^{\mathrm{a}}$ & $3.48^{\mathrm{a}}$ & $24.2^{\mathrm{a}}$ \\
TAL379 & $42.78^{\mathrm{bc}}$ & $0.57^{\mathrm{a}}$ & $36.00^{\mathrm{a}}$ & $2.93^{\mathrm{b}}$ & $16.0^{\mathrm{abc}}$ \\
N+ & $28.44^{\mathrm{c}}$ & $0.33^{\mathrm{a}}$ & $38.33^{\mathrm{a}}$ & $3.10^{\mathrm{b}}$ & $22.1^{\mathrm{ab}}$ \\
N- & $55.45^{\mathrm{a}}$ & $0.60^{\mathrm{a}}$ & $38.56^{\mathrm{a}}$ & $2.40^{\mathrm{b}}$ & $14.7^{\mathrm{bc}}$ \\
GMR120C*SR20A & $58.00^{\mathrm{a}}$ & $0.58^{\mathrm{a}}$ & $35.78^{\mathrm{a}}$ & $3.88^{\mathrm{a}}$ & $13.5^{\mathrm{bc}}$ \\
GMR125B*SR20A & $32.00^{\mathrm{c}}$ & $0.48^{\mathrm{a}}$ & $34.44^{\mathrm{a}}$ & $3.51^{\mathrm{a}}$ & $14.5^{\mathrm{bc}}$ \\
TAL379*SR20A & $43.0^{\mathrm{bc}}$ & $0.51^{\mathrm{a}}$ & $34.33^{\mathrm{a}}$ & $3.00^{\mathrm{b}}$ & $12.0^{\mathrm{c}}$ \\
Dembi 5tation of Debrezeit ARC field site & & & \\
GMR120C & $69.67^{\mathrm{bc}}$ & $1.08^{\mathrm{ac}}$ & $40.33^{\mathrm{a}}$ & $3.63^{\mathrm{ab}}$ & $22.1^{\mathrm{abc}}$ \\
GMR125B & $116.67^{\mathrm{ab}}$ & $1.27^{\mathrm{ac}}$ & $36.33^{\mathrm{abc}}$ & $3.48^{\mathrm{abc}}$ & $15.6^{\mathrm{ab}}$ \\
TAL379 & $10.0^{\mathrm{d}}$ & $0.16^{\mathrm{de}}$ & $35.33^{\mathrm{abc}}$ & $2.90^{\mathrm{cd}}$ & $8.4^{\mathrm{c}}$ \\
N+ & $4.56^{\mathrm{d}}$ & $0.02^{\mathrm{de}}$ & $25.67^{\mathrm{c}}$ & $3.13^{\mathrm{bcd}}$ & $16.8^{\mathrm{bc}}$ \\
N- & $10.37^{\mathrm{d}}$ & $0.08^{\mathrm{de}}$ & $27.00^{\mathrm{bc}}$ & $2.20^{\mathrm{d}}$ & $7.4^{\mathrm{c}}$ \\
GMR120C*SR20A & $33.0^{\mathrm{c}}$ & $0.88^{\mathrm{ac}}$ & $34.67^{\mathrm{abc}}$ & $3.88^{\mathrm{a}}$ & $15.1^{\mathrm{ab}}$ \\
GMR125B*SR20A & $131.67^{\mathrm{ab}}$ & $1.67^{\mathrm{ac}}$ & $39.33 \mathrm{ab}$ & $3.58^{\mathrm{ab}}$ & $25.0^{\mathrm{a}}$ \\
TAL379*SR20A & $10.35^{\mathrm{d}}$ & $0.91^{\mathrm{de}}$ & $29.67^{\mathrm{abc}}$ & $2.97^{\mathrm{dc}}$ & $7.4^{\mathrm{c}}$ \\
\hline
\end{tabular}

NN nodule number, NDW nodule dry weight, SH shoot height, TN\% shoot total nitrogen percent, SDW shoot dry weight. Values raised to different letters in a column are significantly different at $p \leq 0.05$

Table 6 Effects of different treatments on yield and related traits of soybean at the two field sites

\begin{tabular}{llllll}
\hline Treatment & NPP & NSPPD & NSPPL & TSW (g) & GY (tons ha $\mathbf{~}^{-1}$ ) \\
\hline Bako ARC field site & & & & & \\
GMR120C & $37^{\mathrm{a}}$ & $2.07^{\mathrm{ab}}$ & $77^{\mathrm{a}}$ & $212.2^{\mathrm{a}}$ & $3.81^{\mathrm{a}}$ \\
GMR125B & $44^{\mathrm{a}}$ & $2.28^{\mathrm{a}}$ & $102^{\mathrm{a}}$ & $175.08^{\mathrm{a}}$ & $3.16^{\mathrm{a}}$ \\
TAL379 & $39^{\mathrm{a}}$ & $2.17^{\mathrm{ab}}$ & $86^{\mathrm{a}}$ & $165.74^{\mathrm{a}}$ & $2.41^{\mathrm{a}}$ \\
N+ & $39^{\mathrm{a}}$ & $1.91^{\mathrm{b}}$ & $74^{\mathrm{a}}$ & $180.01^{\mathrm{a}}$ & $2.82^{\mathrm{a}}$ \\
N- & $32^{\mathrm{a}}$ & $2.16^{\mathrm{ab}}$ & $70^{\mathrm{a}}$ & $169.29^{\mathrm{a}}$ & $2.69^{\mathrm{a}}$ \\
GMR120C*SR20A & $42^{\mathrm{a}}$ & $2.08^{\mathrm{ab}}$ & $88^{\mathrm{a}}$ & $171.23^{\mathrm{a}}$ & $3.51^{\mathrm{a}}$ \\
GMR125B*SR20A & $40^{\mathrm{a}}$ & $2.08^{\mathrm{ab}}$ & $76^{\mathrm{a}}$ & $191.30^{\mathrm{a}}$ & $3.70^{\mathrm{a}}$ \\
TAL379*SR20A & $32^{\mathrm{a}}$ & $2.09^{\mathrm{ab}}$ & $67^{\mathrm{a}}$ & $168.00^{\mathrm{a}}$ & $2.43^{\mathrm{a}}$ \\
Dembi 5tation of DARC field site & & & \\
GMR120C & $102.0^{\mathrm{a}}$ & $1.64^{\mathrm{ad}}$ & $159 \mathrm{a}^{\mathrm{ab}}$ & $173.85^{\mathrm{a}}$ & $3.97^{\mathrm{a}}$ \\
GMR125B & $72^{\mathrm{ac}}$ & $1.87^{\mathrm{ac}}$ & $133^{\mathrm{abc}}$ & $175.35^{\mathrm{a}}$ & $3.24^{\mathrm{ab}}$ \\
TAL379 & $35^{\mathrm{c}}$ & $1.54^{\mathrm{bd}}$ & $54^{\mathrm{d}}$ & $156.52^{\mathrm{a}}$ & $1.30^{\mathrm{c}}$ \\
N+ & $64^{\mathrm{abc}}$ & $1.25^{\mathrm{d}}$ & $71^{\mathrm{cd}}$ & $173.0^{\mathrm{a}}$ & $2.11^{\mathrm{bc}}$ \\
N- & $55^{\mathrm{bc}}$ & $1.44^{\mathrm{cd}}$ & $81^{\mathrm{d}}$ & $162.0^{\mathrm{a}}$ & $1.37^{\mathrm{c}}$ \\
GMR120C*SR20A & $51^{\mathrm{bc}}$ & $1.82^{\mathrm{ac}}$ & $96^{\mathrm{ac}}$ & $183.50^{\mathrm{a}}$ & $3.35^{\mathrm{ab}}$ \\
GMR125B*SR20A & $85^{\mathrm{ab}}$ & $2.08^{\mathrm{a}}$ & $176^{\mathrm{ab}}$ & $192.95^{\mathrm{a}}$ & $3.98^{\mathrm{a}}$ \\
TAL379*SR20A & $39^{\mathrm{c}}$ & $1.55^{\mathrm{bd}}$ & $60^{\mathrm{c}}$ & $163.0^{\mathrm{a}}$ & $1.60^{\mathrm{c}}$ \\
\hline
\end{tabular}

NPP number of pods per plant, NSPPD number of pods per plant, NSPPL number of seeds per plant, $T S W$ thousands of seed weight, $G Y$ grain yield. Values raised to different letters in a column are significantly different $(p \leq 0.05)$
GMR125B-SR20A co-inoculations increased the grain yield from 3.16 to 3.70 and from 3.24 to 3.98 tons ha $^{-1}$ at Bako ARC and Dembi station of Debrezeit ARC, respectively. The increase was over a half ton $\mathrm{ha}^{-1}$ at each field site. GMR120C and GMR125A inoculations (individually or each with SR20A) outperformed nitrogen fertilization and the reference $B$. japonicum inoculation at both field sites. GMR inoculation increased 12-35\% (Bako ARC) and $53-87 \%$ (Dembi station of Debrezeit ARC) grain yield over nitrogen fertilization. GMR inoculation also increased 30-57\% (Bako ARC) and 103-149\%\% (Dembi station of Debrezeit ARC) grain yield over inoculation of the reference $B$. japonicum. Statistically insignificant variations were also encountered in thousands of seed weight among different treatments at both field sites (Table 6).

Mean comparisons of various parameters recorded at the two field sites The overall mean nodule number and mean nodule dry weight of all treatments were significantly higher at Dembi station of Debrezeit ARC than that of Bako ARC at $p \leq 0.05$ (Table 7). Statistically insignificant differences were observed in shoot height, shoot dry weight and shoot total nitrogen percent between the two field sites.

The overall mean number of pods plant ${ }^{-1}$ (NPP) and number of seeds plant $^{-1}$ (NSPPL) were significantly higher at Dembi station of Debrezeit ARC than Bako ARC $(\mathrm{p} \leq 0.05)$ corresponding to the higher nodule number and dry weight. However, significantly higher number of seeds per pod was recorded at Bako ARC than Dembi station of Debrezeit ARC $(\mathrm{p} \leq 0.05)$. No significant variations were recorded in terms of grain yield and thousand grain weight between the two field sites (Table 7).

Effects of replications, GMR, location and GMR*location interaction Replication (rep) showed significant effect on shoot height, shoot TN\%, on the number of seeds plant $^{-1}$ (NSPPl) and thousands of seed weight (TSW) whereas GMR showed highly significant effect on nodule number $(\mathrm{NN})$ and shoot TN\% at Bako ARC field site $(\mathrm{p} \leq 0.05)$ (Table 8). On the other hand, GMR imposed highly significant effect on nodule number $(\mathrm{NN})$ and nodule dry weight (NDW), shoot TN\%, number of seeds plant $^{-1}$ (NSPPL) and grain yield (GY) at Dembi station of Debrezeit ARC field site with lower MPN $\left(2.2 \times 10^{1}\right)$ of soil soybean rhizobia compared to Bako ARC with 6.3 $\mathrm{X} 10^{3} \mathrm{MPN}$ of soil soybean rhizobia (Tables 1 and 8 ). However, replication (rep) showed no significant effect on all the nodulation, growth, yield and yield related parameters at Dembi station of Debrezeit ARC field site.

Combined ANOVA of the two field sites revealed the effect of the GMR on more nodulation, growth and yield traits of the crop than location (Loc), 
Table 7 Mean comparison of various parameters recorded for all treatments at the two field sites

\begin{tabular}{|c|c|c|c|c|c|}
\hline \multirow[t]{2}{*}{ Field sites } & \multicolumn{5}{|c|}{ Nodulation and growth parameters } \\
\hline & $\mathrm{SH}(\mathrm{cm})$ & NN & NDW (g) & SDW (g) & TN\% \\
\hline BARC & $36.3^{\mathrm{a}}$ & $44^{\mathrm{b}}$ & $0.519^{b}$ & $16.575^{\mathrm{a}}$ & $3.23^{\mathrm{a}}$ \\
\hline \multirow[t]{3}{*}{ DDARC } & $34.9^{\mathrm{a}}$ & $81.91^{\mathrm{a}}$ & $1.094^{\mathrm{a}}$ & $17.308^{\mathrm{a}}$ & $3.42^{\mathrm{a}}$ \\
\hline & \multicolumn{5}{|c|}{ Yield and yield related parameters } \\
\hline & NPP & NSPPD & NSPPL & TSW (g) & GY (tons ha $\mathrm{h}^{-1}$ ) \\
\hline BARC & $38.13^{b}$ & $2.11^{\mathrm{a}}$ & $80.00^{b}$ & $179.11^{\mathrm{a}}$ & $3.066^{\mathrm{a}}$ \\
\hline DDARC & $66.67^{a}$ & $1.74^{b}$ & $127.94^{\mathrm{a}}$ & $182.38^{\mathrm{a}}$ & $3.076^{\mathrm{a}}$ \\
\hline
\end{tabular}

NN nodule number, NDW nodule dry weight, SH shoot height, TN shoot total nitrogen percent, SDW shoot dry weight, NPP number of pods per plant, NSPPD number of pods per plant, NSPPL number of seeds per plant, TSW thousands of seed weight, GY grain yield. Values raised to different letters in a column are significantly $(\mathrm{p} \leq 0.05)$ different

Table 8 Effects of rep, GMR, loc and GMR*Loc interactions on various parameters of soybean at the field sites

\begin{tabular}{|c|c|c|c|c|c|c|c|c|c|c|}
\hline Site & NN & NDW & $\mathrm{SH}$ & SDW & TN\% & NPP & NSPPD & NSPPL & TSW & GY \\
\hline \multicolumn{11}{|c|}{ Effects of replication (rep) and GMR on growth, nodulation and yield } \\
\hline \multicolumn{11}{|l|}{ BARC } \\
\hline rep & NS & NS & * & NS & $*$ & NS & NS & * & * & NS \\
\hline GMR & ** & NS & NS & NS & ** & NS & NS & NS & NS & NS \\
\hline $\mathrm{CV}$ & 9 & 12 & 8 & 10 & 17 & 7 & 9 & 7 & 16 & 22 \\
\hline \multicolumn{11}{|l|}{ DDARC } \\
\hline rep & NS & NS & NS & NS & NS & NS & NS & NS & NS & NS \\
\hline GMR & $* *$ & $* *$ & NS & * & $* *$ & * & NS & $* *$ & NS & $* *$ \\
\hline $\mathrm{cV}$ & 15 & 18 & 18 & 21 & 15 & 13 & 17 & 11 & 21 & 19 \\
\hline \multicolumn{11}{|c|}{ Combined ANOVA: Effects of location, rep, and GMR-location interaction } \\
\hline LoC & NS & NS & NS & * & NS & $* *$ & $* *$ & NS & NS & NS \\
\hline Rep & NS & NS & * & NS & NS & NS & NS & NS & NS & NS \\
\hline GMR & ** & ** & NS & ** & ** & NS & ** & ** & NS & $* *$ \\
\hline $\mathrm{GMR}^{*} \mathrm{loc}$ & $* *$ & $* *$ & * & * & NS & NS & NS & NS & NS & NS \\
\hline$C V$ & 10 & 15 & 15 & 18 & 15 & 12 & 11 & 10 & 21 & 19 \\
\hline
\end{tabular}

NS not significant, *(significant), ${ }^{* *}$ (highly significant) at $\mathrm{p} \leq 0.05$

NN nodule number, NDW nodule dry weight, SH shoot height, SDW shoot dry weight, TN\% total nitrogen percent of shoot, NPP number of pods per plant, NSPPD number of seeds per pod, NSPPL number of seeds per plant, TSW thousands of seed weight, GY grain yield, rep replication, GMR Glycine max rhizobiia, loc location, GMR*Ioc GMR-location interaction, CV coefficient of variance, BARC Bako Agricultural Research Center, DDARC Dembi Station of Debrezeit Agricultural Research Center

replication (Rep) and GMR*Loc interaction. GMR showed highly significant effect on NN, NDW, SDW, shoot TN\%, NSPPD, NSPPL and GY (Table 8). Location showed highly significant effect on NPP and NSPPD whereas GMR*Loc interaction showed highly significant effect on NN and NDW alone. Replication (rep) showed a significant effect only on shoot height (SH).

Correlation test A significant or highly significant positive correlations were recorded among many variables (Table 9). Number of pods plant ${ }^{-1}$ (NPP) showed a highly significant positive correlation with nodule number, nodule dry matter, shoot total nitrogen and shoot dry matter with Person's $r \geq 0.59$. Number of seeds $\operatorname{pod}^{-1}$ was highly significantly correlated with number of nodules plant ${ }^{-1}$ and number of pods plant ${ }^{-1}$ whereas number of seeds plant ${ }^{-1}$ was significantly correlated with shoot height (Table 9). There was also a highly significant positive correlation between grain yield (GY) and nodule number, nodule dry matter, number of pods plant ${ }^{-1}$ and number of seeds pod ${ }^{-1}$ with Person's $r \geq 0.63$. Insignificant negative correlations were encountered in few cases. 
Table 9 Correlations among different variables in the field trials

\begin{tabular}{|c|c|c|c|c|c|c|c|c|c|c|}
\hline & SH & NN & NDW & TN & SDW & NPP & NSPPD & NSPPL & TSW & GY \\
\hline SH & 1 & & & & & & & & & \\
\hline NN & 0.2 & 1 & & & & & & & & \\
\hline NDW & -0.09 & $0.57^{*}$ & 1 & & & & & & & \\
\hline TN & -0.24 & 0.42 & $0.76^{* *}$ & 1 & & & & & & \\
\hline SDW & -0.23 & 0.42 & $0.77^{* *}$ & $0.9997^{* *}$ & 1 & & & & & \\
\hline NPP & 0.13 & $0.59^{* *}$ & $0.68^{* *}$ & $0.76^{* *}$ & $0.77^{* *}$ & 1 & & & & \\
\hline NSPPD & 0.13 & $0.61^{* *}$ & 0.43 & $0.56^{*}$ & $0.57^{*}$ & $0.60^{* *}$ & 1 & & & \\
\hline NSPPL & $0.57^{*}$ & 0.16 & -0.05 & 0.09 & 0.1 & 0.13 & 0.39 & 1 & & \\
\hline TSW & 0.11 & $0.79^{* *}$ & $0.70^{* *}$ & $0.67^{* *}$ & $0.67^{* *}$ & $0.71^{* *}$ & $0.76^{* *}$ & 0.2 & 1 & \\
\hline GY & 0.17 & $0.99 * *$ & $0.63^{* *}$ & $0.47^{*}$ & $0.48^{*}$ & $0.64^{* *}$ & $0.63^{* *}$ & 0.14 & $0.82^{* *}$ & 1 \\
\hline
\end{tabular}

* significant correlation, ${ }^{* *}$ highly significant correlation

NN nodule number, NDW nodule dry weight, SH shoot height, SDW shoot dry weight, TN\% total nitrogen percent of shoot, NPP number of pods per plant, NSPPD number of seeds per pod, NSPPL number of seeds per plant, TSW thousands of seed weight, GY grain yield

\section{Discussion}

Based on authentication tests, generation time (g), colony diameter and BTB-YMA color changes (Jordan, 1982), ten GMR were identified as fast growing soybean rhizobia similar to earlier reports (Scholla and Elkan 1984; Young et al. 1988; Chen et al. 1988; Hungria et al. 2001) whereas the two remaining GMR were identified as slow growing soybean rhizobia in line with previous reports (Sadowsky et al. 1983; Singh et al. 2013). Thus, the fast growing GMR and slow growing GMR belong to the genus Sinorhizobium and Bradyrhizobium, respectively (Table 2) according to the current taxonomy of soybean rhizobia though further characterizations involving genetic method should be employed to verify the genera and further identify the species to which they belong.

Features of the GMR like irregular colonies with less exopolysaccharides (Sadowsky et al. 1983) and shiny translucent colonies with entire margin (Chen et al. 1988) for fast growing soybean rhizobia as well as irregular colonies and less exopolysaccharides (Fuhrmann 1990) and shiny translucent colonies with entire margin. (Zhang et al. 2012) for slow growing soybean rhizobia were also reported previously. This shows GMR reported here and previously have diverse colony features.

Fast growing GMR showed better salt $(\mathrm{NaCl})$ tolerance than slow growers similar to most previous reports on soybean rhizobia (Sadowsky et al. 1983; Chen et al. 1988; Youseif et al. 2014). GMR also showed higher temperature tolerance regardless of their taxonomic position as identified by Hungria et al. (2001) and Singh et al. (2013) though the highest growth temperature $\left(45^{\circ} \mathrm{C}\right)$ was recorded for two fast growers. Mechanisms which enhance salt $(\mathrm{NaCl})$ tolerance in bacteria include up take $\mathrm{K}^{\div}$, synthesis and increase in intracellular glutamate, proline and glycine betaine (Rudulie, and Bernard 1986). Increased levels of chaperones was also indicated as a method of rhizobial adaptation to higher temperature as higher amounts of chaperones prevent protein denaturation and permit proper protein folding and mRNA stability (Alexandre and Oliveira 2010). The whole GMR were acid sensitive failing to grow at $\mathrm{pH}$ lower than 5 , but they are potentially adapted to alkaline environment as all grew at $\mathrm{pH} 9.5$ though they originated from slightly acidic soil ( $\mathrm{pH} 5.9$ to 6.4). $\mathrm{pH}$ impacts microbial cell growth and functions via influencing protein and nucleic acid syntheses, nutrient uptake, degradation and utilization (Guan et al. 2013). Similarly, GMR resisted some antibiotics and heavy metals, but they were sensitive to some other antibiotics, heavy metals and recommended doses of agrochemicals. Rhizobia heavy metal tolerance mechanisms encompass heavy metal adsorption and accumulation, and release of some enzymes and bioactive metabolites to facilitate their removal (Hao et al 2014) Antibiotic modification, antibiotic efflux and target modification constitutes bacterial antibiotic resistance mechanism (Peterson and Kaur 2018) Degradation of some fungicides by rhizobia was also reported by Moawad et al (2014). Tolerance against these chemicals impart them survival advantages in the soil as several soil microbes produce antibiotics (Huck et al. 1991), various natural and anthropogenic processes release heavy metals into soil, water, air and their interface (Masindi and Muedi 2018) and fungicide seed treatments and post seedling emergence application of herbicide like glyphosate is common in soybean production (Bierman et al. 2006). Generally, GMR were sensitivity to the tested agrochemicals implying the potential harmful effects of the chemicals on non-target soil microbial populations. 
GMR efficiently utilized most of the carbon and nitrogen sources as demonstrated via their growth. This is important to grow them on alternative available substrates in laboratory and can contribute to their survival in soils where such substrates may be exudated from roots or released as a result of decomposition of complex soil organic matter. Fast growers generally demonstrated utilization of wider ranges of carbon and nitrogen sources in line with other reports (Sadowsky et al. 1983; Young et al. 1988; Ansari and Rao 2014). However, a fast growing GMR102 failed to utilize 50\% of the amino acids. Variation in bacterial utilization of organic substrates relies on their physiological capacities and substrate complexity (Koranda et al. 2014).

IAA production varied significantly among the GMR $(\mathrm{p} \leq 0.05)$ being as low as $2.5 \mu \mathrm{M}$ for a Bradyrhizobium sp. (GMR46) and as high as $116 \mu \mathrm{M}$ for a Sinorhizobium sp. (GMR45) falling within the range previously reported by Chen et al. (2002) for soybean rhizobia. Bacterial IAA improves the plant's accessibility to soil nutrients by increasing root length and surface area, but it suppresses plant growth when the endogenous level is optimal as plant hormones are required at very low concentration (Glick 2012). GHR were not good phosphate solubilizers as the maximum aluminium phosphate and tri-calcium phosphate solubilization index of the GMR (1.6) was lower than previous value (3.2) reported by Jadhav (2013) and no GMR managed to solubilize $\mathrm{FePO}_{4}$. Phosphate solubilizing bacteria liberate phosphorus from insoluble complexes formed among phosphate anions $\left(\mathrm{H}_{2} \mathrm{PO}_{4}{ }^{-1}\right.$ and $\left.\mathrm{HPO}_{4}{ }^{-2}\right)$ and $\mathrm{Fe}, \mathrm{Al}$ or $\mathrm{Mn}$ between $\mathrm{pH} 5.5$ to 7.00 (Ahemad and Khan 2011). Bacterial solubilization of inorganic phosphate is associated with the production of low molecular weight organic acid (Rodriguez et al. 2006). Protease activity demonstrated by the GMR might have contributed to anti-Fusarium oxysporum activity recorded for GMR79 (33\% PIRG) and GMR102 (17\% PIRG) as described by Kim et al. (2008). However, these fungal antagonistic GMR did not demonstrate chitinase and HCN production which are also known to be fungal inhibitors (Ordentlich et al. 1988; Dowling and O'Gura 1994).

Cluster analysis based on phenotypic traits separated a Bradyrhizobium sp. (GMR46) from the rest rhizobia at lower level percent of similarity level as it was unique in being sensitive to all the test antibiotics. Bradyrhizobium spp. and Sinorhizobium spp were also clustered together implying that taxonomically distinct bacteria can share large percentage of phenotypic similarities. No clustering was formed above about $87 \%$ similarity level indicating the existence of phenotypic distinctiveness among the GMR.
GMR varied in their nodulation and associated effectiveness in which two Sinorhizobium spp. (GMR120C and GMR125B) were superior. Abundant nodulation of the two selected Sinorhizobium spp. (GMR120C and GMR125) inoculated plants indicates their higher infective traits. Their inoculation resulted in well growth of plants with greener leaves indicating their promising symbiotic performance. The greenhouse symbiotic effectiveness (100 to 170\%) recorded for these two GMR was rated as highly effective according to Lalande et al. (1990). They were also compatible to the three experimental cultivars of soybean and the co-inoculated PGP Achromobacterium sp. (SR20A), efficient in utilizing different carbon and nitrogen substrates and good in stress tolerances showing their potential ecological fitness. All of these have been considered as desirable features of inoculants (Howieson et al. 2000).

Field inoculated soybean plants showed response in terms of nodulation, growth, yield and yield related parameters. Inoculation of the two selected Sinorhizobium spp. (GMR120C and GMR125B) resulted in good growth of plants with greener leaves and abundant branches implying their effectiveness. Their single or coinoculation with the plant growth promoting Achromobacter sp. (SR20A) induced significantly higher nodules than the control treatments and reference $B$. japonicum at Dembi station of Debrezeit ARC with lesser MPN of background soybean rhizobia $\left(2.2 \times 10^{1}\right)$ than that of Bako ARC field site soil with $6.3 \times 10^{3} \mathrm{MPN}$ of soybean rhizobia. This is likely due to the higher interference of higher number of background soybean rhizobia in the latter case as previously described by Singleton and Tavares (1986). The nodules induced by GMR120C and GMR125B were well developed and pink indicating they are Effective nodules according to Kukkamalla1 and Vardhan (2016). The least number of nodules recorded for $\mathrm{N}$-fertilized plants at both field sites could be due to the nodulation inhibitive effect of soil available nitrogen (Kinkema et al. 2006). The nodule number and nodule dry weight of GMR inoculated plants reported here were greater than those reported from India by Jaiswal et al. (2017) as a result of inoculating soybean with different rhizobia. Shoot total nitrogen percent was consistently higher for GMR inoculations unlike shoot height and dry matter. The exotic B. japonicum (TAL379) showed poor nodulation as revealed even under field condition with fewer MPN background soybean rhizobia. Moreover, TAL379 induced small white nodules indicating, the strain is not only less infective but also ineffective under the given field conditions. However, Solomon et al. (2012) reported the formation of abundant nodules on the currently reported soybean cultivar under field conditions but having no indigenous soybean rhizobia. Exotic 
rhizobial inoculants often fail to improve growth and yield leguminous crops as a result of highly competitive indigenous rhizobia in the soil, strain-cultivar incompatibility or unfavorable environmental conditions (Hungria et al., 2009).

The grain yielded due to Sinorhizobium spp. (GMR120C and GMR125A) inoculation reported here (3.16-3.97 tons ha ${ }^{-1}$ ) are much better than 2.17, 2.52 and 2.56 tons ha $^{-1}$ reported by Merkeb et al. (2016) Abera et al. (2015), and Sisay et al. (2019), respectively. Jaiswal et al. (2017) reported even a lower grain yield ranging from 1.31 to 1.59 tons $\mathrm{ha}^{-1}$ for soybean plants inoculated with different soybean rhizobial strains. However Leggett et al. (2017), reported a higher grain yield (3.70 tons ha- ${ }^{1}$ ) for several soybean inoculation under different field conditions in USA which is also comparable to the present report. Grain yield improvement showed the establishment of effective symbiosis by the fast growing GMR (Sinorhizobium spp.) in line with previous reports (Dowdle and Bohlool. 1985, Isreal et al. 1986; Hungria et al. 2001) though Bradyrhizobium has commonly been used as soybean inoculant. Hungria et al. (2001) also stressed the great commercial interest in fast growing soybean rhizobia as it saves time for their mass production compared to slow growers.

The overall significantly lower mean nodule number $(\mathrm{p} \leq 0.05)$ accompanied by lower mean nodule dry weight recorded at Bako ARC with higher MPN of soil soybean rhizobia could be due to the impact of the higher background rhizobia as described by Thies et al. (1991), It also indicates the lower nodulating traits of the higher native soil rhizobia at Bako ARC field site. Relatively higher seed yield was recorded at Dembi station of Debrezeit ARC than Bako ARC due to higher number of pods per plant (NPP) and number of seeds per plant (NSPPL) at the former field site as pointed out by Board et al. (2003). The means of various parameters (Table 7) represent means of all treatments including controls and the ineffective reference B. japonicum inoculation for which lower results were recorded. So the means would be higher than the indicated values if they were computed for the effective GMR inoculations excluding values for controls and the reference $B$. japonicum inoculation.

GMR imposed significant or highly significant effect $(p \leq 0.05)$ on $70 \%$ of the tested nodulation, growth, yield and yield related parameters at Dembi station of Debrezeit ARC field site compared to $20 \%$ in the case of Bako ARC site with higher MPN of indigenous soybean rhizobia. Singleton and Tavares (1986) indicated that statistically significant inoculation responses can be avoided in the presence of as few as 20 indigenous rhizobia $\mathrm{g}^{-1}$ of soil with some effective strains under greenhouse experimental conditions. At both field sites GMR inoculation showed highly significant effect on the number of nodules similar to the report of Samudin and Kuswantoro (2018). Replication (rep) showed significant effect on few (Bako ARC) and on none of (Dmbi Station of DAR) the tested nodulation, growth, yield and related parameters indicating it was not as important factor as GMR inoculation.

Combined ANOVA of the two field sites revealed highly significant effect of the GMR inoculation on $70 \%$ of the tested nodulation, growth, yield and yield related traits of the crop in contrast to replication (Rep), location (Loc), and GMR*Loc interaction that showed significant or highly significant effect on $10 \%, 30 \%$ and $40 \%$ of the tested parameters, respectively implying inoculation of GMR was a more important factor. Solomon et al. (2012) reported significant effect of rhizobial inoculation on the number and dry matter of nodules, plant dry matter and total nitrogen, number of seeds $\operatorname{pod}^{-1}$ and plant ${ }^{-1}$, and on grain yield similar to the current report. However, the authors reported highly significant effect of the rhizobial strains on the thousands of seed weight (TSW) contrary to the current report.

The higher nodulation trait of the two Sinorhizobium spp. (GMR120C and GMR125B) had contributed to yield improvement as the number of nodules was highly significant correlated with the number of pods plant ${ }^{-1}$ $(r=0.59)$, number of seeds per pod $(r=0.61)$ and grain yield $(r=0.99)$ implying they have better infection trait to induce nodules and better symbiotic effeteness to fix nitrogen.

\section{Conclusion}

The indigenous Glycine max [L] Merr. rhizobia (GMR) were diverse as revealed by cultural, stress tolerance, the overall phenotypic variability analysis and symbiotic features. Most of them grew faster and produced acid with larger colonies and hence identified as Sinorhizobium spp. Members of the Sinorhizobium spp. metabolized wider range of substrates, showed better tolerance to higher salt $(\mathrm{NaCl})$ concentration and temperature levels. However, only two Sinorhizobium spp. (GMR120C and GMR125B) well nodulated different cultivars of soybean (green house) and improved grain yield under field conditions showing their potential to be used as inoculant. For better outcome, GMR120C should be inoculated singly whereas GMR125B should be co-inoculated with the PGP Achromobacterium sp. as shown in the field experiment. Sequence analysis of genes like $16 \mathrm{~S}$ rRNA should be performed to verify the suggested taxonomic placement of the GMR. 


\section{Abbreviations}

ARC: Agricultural Research Center; BTB: Bromothymol blue; GMR: Glycine max Rhizobia; IAA: Indol 3-acetic acid; MPN: Most probable number; PGP: Plant growth promoting; PIRG: Percentage of inhibition of radial growth; YMA: Yeast extract mannitol agar; YMB: Yeast extract mannitol broth.

\section{Acknowledgements}

The authors would like to acknowledge Addis Ababa University and Madda Walabu University for their financial support. The authors thank Microbial, Cellular and Molecular Biology Department, Addis Ababa University for laboratory facility. We would also like to appreciate Bako Agricultural Research center for providing soybean seeds, Bako Agricultural and Debrezeit Agricultural Research Centers for providing land to execute field experiments. We also would like to forward our appreciation to the National Soil Testing Center of Ethiopia for providing reference bacterial stain and carrier material. The authors also express their gratitude to Mr. Zerihun Abebe of Bako Agricultural Research Center for his technical assistant during field experiment. We also forward our heartfelt gratitude to Dr. Marta Maluk for assisting in phenotypic variability data analysis. We would also like to greatly thank the editor, the two anonymous reviewers and the Corrections Team for their constructive comments that had improved the article.

\section{Authors' contributions}

Both authors identified the research problem and prepared the research design. DT performed laboratory and field experimental works under the supervision of FA. Both authors wrote the manuscript. Both authors read and approved the final manuscript.

\section{Funding}

The research was funded by the School of Graduate Studies of Addis Ababa University and also by Madda Walabu University. No fund was received from any other funding agencies or business or non-profit sectors. All the research activities and writing the article were executed by the authors.

\section{Availability of data and materials}

The datasets generated and/or analysed during the current study are available in the Addis Ababa University repository. The study soybean rhizobia are deposited in Soil and Environmental Microbiology Laboratory, College of Natural Sciences, Addis Ababa, Ethiopia.

\section{Ethics approval and consent to participate}

Not applicable.

\section{Consent for publication}

Not applicable.

\section{Competing interests}

The authors declare that they have no competing interests.

\section{Author details}

${ }^{1}$ Department of Biology, College of Natural and Computation Sciences, Madda Walabu University, P.O.Box 437, Bale Robe, Ethiopia. ${ }^{2}$ Department of Microbial, Cellular and Molecular Biology, Faculty of Life Sciences, College of Natural Science, Addis Ababa University, P.O.Box 1176, Addis Ababa, Ethiopia.

Received: 3 September 2020 Accepted: 22 November 2020

\section{Published online: 28 November 2020}

\section{References}

Abebe A (1986) Culture collection of Rhizobium strains of important pulses of Ethiopia. In: Paper presented at IFS Workshop on biological improvement of soil fertility. 19-25 March 1986. Dakar, Senegal

Abera T, Semu E, Debele T, Wegary D, Kim H (2015) Determination soil rhizobium populations, intrinsic antibiotic resistance, nodulation and seed yield of faba bean and soybean in Western Ethiopia. World J Agri Sciences 11:311-324
Ahemad M, Khan MS (2010) Influence of selective herbicides on plant growth promoting traits of phosphate solubilizing Enterobacter asburiae strain PS2. Res J Microbiol 5(9):849-857

Ahemad M, Khan MS (2011) Ecological assessment of biotoxicity of pesticides towards plant growth promoting activities of pea (Pisum sativum)-specific Rhizobium sp. Strain MRP1. Emir J Food Agric 24:334-343

Ahemad M, Khan MS (2012) Ecological assessment of biotoxicity of pesticides towards plant growth promoting activities of pea (Pisum sativum)specificRhizobium sp. Strain MRP1. Emir J Food Agric 24:334-343

Alexandre A, Oliveira S (2010) Most heat-tolerant rhizobia show high induction of major chaperone genes upon stress. FEMS Microbiol Ecol 75:28-36

Amarger NO, Macheret V, Laguerre G (1997) Rhizobium gallicum sp. nov. and Rhizobium giardinii sp. nov., from Phaseolus Vulgaris nodules. Int J Syst Evol Microbiol 47:996-1006

Ansari PG, Rao DLN (2014) Differentiating indigenous soybean Bradyrhizobium and Rhizobium spp. of Indian soils. Indian J Microbiol 54:190-195

Appunu C, N'Zoue A, Laguerre G (2008) Genetic Diversity of native bradyrhizobia isolated from soybeans (Glycine max L.) in different agricultural-ecological-climatic regions of India. Appl Environ Microbiol 74:5991-5996

Argaw A (2012) Evaluation of co-inoculation of Bradyrhizobium japonicum and phosphate solubilizing Pseudomonas spp. effect on Soybean (Glycine max L. (Merr.) in Assossa Area. J Agric Sci Technol 14:213-224

Argaw A (2014) Symbiotic effectiveness of inoculation with Bradyrhizobium isolates on soybean [Glycine max (L.) Merrill] genotypes with different maturities. Springerplus 3:1-13

Aserse A, Räsänen LA, Aseffa F, Hailemariam A, Lindström K (2012) Phylogenetically diverse groups of Bradyrhizobium isolated from nodules of Crotalaria spp., Indigofera spp., Erythrina brucei and Glycine max growing in Ethiopia. Mol Phylogen Evol 65:595-609

Aung TT, Buranabanyat B, Piromyou P, Longtonglang A, Tittabutr P, Boonkerd $N$, Teaumroong N (2013) Enhanced soybean biomass by co-inoculation of Bradyrhizobium japonicum and plant growth promoting rhizobacteria and its effects on microbial community structures. Afr J Microbiol Res 7:3858-3873

Bansode VB, Bajekal SS (2006) Characterization of chitinase from organisms from Lonar Lake. Indian J Biotechnol 5:357-363

Bierman RE, Riechers D, Sprague CL, Bollero GWL, (2006) Fungicide-herbicide interaction in soybean (Glycine max). J Crop Prot 25(2):134-139

Board JE, Kang MS, Bodrero ML (2003) Yield components as indirect selection criteria for late-planted soybean cultivars. Agronomy 95:420-429

Broughton WJ, Dilworth MJ (1970) Control of leghaemoglobin synthesis in snake beans. Biochem J 125:1075-1080

Chen WX, Yan GH, Li JL (1988) Numerical taxonomic study of fast-growing soybean rhizobia and a proposal that Rhizobium fredii be assigned to Sinorhizobium gen. nov. Int J Syst Evol Microbiol 38:392-397

Chen W, Wang E, Wang S, Li Y, Chen X, Li Y (1995) Characteristics of Rhizobium tianshanense sp. nov., a moderately and slowly growing root nodule bacterium isolated from an arid saline environment in Xinjiang, People's Republic of China. Int J Syst Bacteriol 45:153-159

Chen LS, Figueredo A, Villani H (2002) Diversity and symbiotic effectiveness of rhizobia isolated from field-grown soybean nodules in Paraguay. Biol Fertil Soils 35:448-457

CSA (2019) Agricultural sample survey 2018/19, Volume I Report on area and production of major crops (private peasant holdings, main rainy season), June 2019, Addis Ababa, Ethiopia

Dashti N, Zhang F, Hynes R, Smith DL (1998) Plant growth promoting rhizobacteria accelerate nodulation and increase nitrogen fixation activity by field grown soybean [Glycine max (L.) Merr.] under short season conditions. Plant Soil 200:205-213

Deresse HD (2019) Soybean research and development in Ethiopia. Acta Sci Agric 3(10):192-194

Dowdle SF, Bohlool BB (1985) Predominance of fast-growing Rhizobium japonicum in soybean fields in the People's Republic of China. Appl Environ Microbiol 50:1171-1176

Dowling DN, O'Gara F (1994) Metabolites of Pseudomonas involved in the biocontrol of plant disease. Trends Biotechnol 12:133-141

Fana DM (2018) The potential for bradyrhizobia and phosphate solubilising microorganisms to improve soybean (Glycine max (L.) Merr.) production in acid soils in Ethiopia, PhD Dissertation, School of Agriculture, Food and Wine, The University of Adelaide 
Fuhrmann J (1990) Symbiotic effectiveness of indigenous soybean bradyrhizobia as related to serological, morphological, rhizobitoxine, and hydrogenase phenotypest. Appl Environ Microbiol 56:224-229

Glick BR (2012) Plant growth-promoting bacteria: mechanisms and applications. Scientifica 2012:1-15

Gomez KA, Gomez A (1984) Statistical procedures for agricultural research, 2nd edn. Wiley, New York

Guan N, Liu L, Shin H, Chen RR, Zhang J, Li J, Du G, Shi Z, Chen J (2013) Systems-level understanding how Propionibacterium acidipropionici respond to propionic acid stress at the microenvironment levels: mechanism and application. J Biotechnol 167:56-63

Hailu M, Kelemu K (2014) Trends in Soy Bean Trade in Ethiopia. Res J Agric Environ Manage 3:477-484

Hao X, Taghavi S, Xie P, Orbach MJ, Alwathnani HA, Rensing C, Wei G (2014) Phytoremediation of heavy and transition metals aided by legume-rhizobia symbiosis. Int J Phytoremediat 16:179-202

Howieson JG, O'Hara GW, Carr SJ (2000) Changing roles for legumes in Mediterranean Agriculture: developments from an Australian perspective. Field Crops Res 65:107-122

Huck TA, Porter N, Bushell ME (1991) Positive selection of antibiotic producing soil isolates. J Gen Microbiol 137:2321-2329

Hungria M, Chueire, LMdeO, Coca RG, Megl'as M, (2001) Preliminary characterization of fast growing rhizobial strains isolated from soyabean nodules in Brazil. Soil Biol Biochem 33:1349-1361

Hungria M, Araujo RS, Campo RJ (2009) Biological nitrogen fixation as a key component of nutrition for the soybean crop in Brazil. World soybean research conference proceedings. Chinese Academy of Agricultural Sciences Beijing 8 December 11, 2009.

Israel DW, Mathis JN, Barbour WM, Elkan GH (1986) Symbiotic effectiveness and host-strain interactions of Rhizobium fredii USDA 191 on different soybean cultivars. App Environ Microbiol 51:898-903

Jadhav RN (2013) Isolation of rhizobia from soybean cultivated in Latur area and study of its phosphate solubilization activity. Bio Disc 4:100-103

Jaiswal SK, Beyan SM, Dakora FD (2016) Distribution, diversity and population composition of soybean-nodulating bradyrhizobia from different agroclimatic regions in Ethiopia. Biol Fertil Soils 52:725-738

Jaiswal SK, Anand A, Vaishampayan A (2017) Response of soybean (Glycine max L. Merr.) cultivars to soil microsymbionts inoculation in agriculture field in India. J plant Sci 12(1):30-38

Jordan DC (1982) NOTES: Transfer of Rhizobium japonicum Buchanan 1980 to Bradyrhizobium gen. nov., a genus of slow-growing, root nodule bacteria from leguminous plants. I J Syst Bacteriol 32:136-139

Kasana RC, Salwan R, Dhar H, Dutt S, Gulati A (2008) A rapid and easy method for the detection of microbial cellulases on agar plates using Gram's iodine. Curr Microbiol 57:503-507

Keyser HH, Ben Bohlool B, Hu TS, Weber DF (1982) Fast-growing rhizobia isolated from root nodules of soybean. Science 215: 1631-1632

Kim YC, Jung H, Kim KY, Park SK (2008) An effective biocontrol bioformulation against Phytophthora blight of pepper using growth mixtures of combined chitinolytic bacteria under different field conditions. Eur J Plant Pathol 120:373-382

Kinkema M, Scott PT, Gresshoff PM (2006) Legume nodulation: successful symbiosis through short- and long-distance signaling. Funct Plant Bio 33:707-721

Koranda M, Kaiser C, Fuchslueger L, Kitzler B, Sessitsch A, Zechmeister-Boltenstern S, Richter A (2014) Fungal and bacterial utilization of organicsubstrates depends on substrate complexity and $\mathrm{N}$ availability. FEMS Microbiol Ecol 87:142-152

Kravchenko I, Kizilova A, Titova L, lutinskaya G (2013) Effect of microbial fertilizers on rhizospheric bacterial diversity and yield response of soybean plants. Agric Sci Dev 2:120-125

Kukkamalla A, Vardhan ZV (2016) A Study on effective and ineffective root nodules of Trigonella foenum- graecum elicited by Bradyrhizobium. OSRJESTFT 10:106-111

Kuykendall LD, Saxena B, Devine TE, Udell SE (1992) Genetic diversity in Bradyrhizobium japonicum Jordan 1982 and a proposal for Bradyrhizobium elkanii sp. nov. Can J Microbiol 38:501-505
Lalande R, Bigwaneza PC, Antoun H (1990) Symbiotic effectiveness of strains of Rhizobium leguminosarum biovar Phaseoli isolated from soils of Rwanda. Plant Soil 121:41-46

Leggett M, Diaz-Zorita M, Koivunen M, Bowman R, Pesek R, Stevenson G, Leister T (2017) Soybean response to inoculation with Bradyrhizobium japonicum in the United States and Argentina. Agron J 109:1031-1038

Leon M, Yaryura PM, Montecchia MS, Hern'andez Al, Correa OS, Pucheu NL, Kerber NL, Garc'ia AF (2009) Antifungal activity of selected indigenous Pseudomonas and Bacillus from the soybean rhizosphere. I J Microbiol 2009:1-9

Lupwayi NZ, Haque I (1994) Legume-rhizobium technology manual, working document. No. 29. Environmental Science Division, International Livestock Center for Africa, Addis Ababa, Ethiopia.

Lwin KM, Myint MM, Tar T, Aung WZM (2012) Isolation of plant hormone (Indole-3aceticacid-IAA) producing rhizobacteria and study on their effects on maize seedling. Eng J 16:137-144

Masciarelli O, Llanes A, Luna V (2014) A new PGPR co-inoculated with Bradyrhizobium japonicum enhances soybean nodulation. Microbiol Res 169:609-615

Masindi V, Muedi KL (2018) Environmental contamination by heavy metals In: Hosam El Din H, Saleh M, Aglan RF, editors. Heavy Metals Intech. Open publisher

Merkeb F, Redi M, Gebremedhin W (2016) Evaluation of different commercial rhizobial strains on soybean (Glycine max L.) yield at Pawe District, Northwestern Ethiopia. W S N 55: 15-26

Moawad H, El-Rahim WMA, Shawky H, Higazy AM, Daw ZY (2014) Evidence of fungicides degradation by rhizobia. Agric Sci 5:618-624

Mubeen F, Shiekh MA, Iqbal T, Khan QM, Malik KA, Hafeez F (2006) In vitro investigation to explore the toxicity of fungicides for plant growth promoting rhizobacteria. Pak J Bot 38:1261-1269

Ogbemudia FO, Denise EM, Ogie-Odia EA, Omonhinmin AC (2010) Comparative germination studies of cowpea (Vigna unguiculata Linn. Walp) and soybean (Glycine max L. Merr) on whole and water saturated fractions of hydrocarbon (Hexane). Annu Biological Res 1:34-40

Ordentlich A, Elad Y, Chet I (1988) The role of chitinase of Serratia marcescens in biocontrol of Sclerotium rolfsii. Phytopathol 78:84-88

Parray JA, Kamili AN, Reshi ZA, Hamid R, Qadri RA (2013) Screening of beneficial properties of rhizobacteria isolated from Saffron (Crocus sativus $\mathrm{L}$ ) rhizosphere. Afr J Microbiol Res 7:2905-2910

Pe'rez E, Sulbar'an M, Ball MM, Yarz'abal LA, (2007) Isolation and Characterization of mineral phosphate-solubilizing bacteria naturally colonizing a limonitic crust in the south-eastern Venezuelan region. Soil Biol Biochem 39:2905-2914

Peterson E, Kaur P (2018) Antibiotic resistance mechanisms in bacteria: relationships between resistance determinants of antibiotic producers, environmental bacteria, and clinical pathogens. Front Microbiol 9:1-21

Purchino HMA, Festin PM, Elkan GH (2000) Identification of effective strains of Bradyrhizobium. Archis Pintoi Trop 77:226-232

Rechiatu A, Nana E, Clement AR (2015) Response of soybean (Glycine max I.) to rhizobia inoculation and molybdenum application in the northern savannah zones of Ghana. J Plant Sci 3:64-70

Rodriguez H, Fraga R, Gonzalez T, Bashan Y (2006) Genetics of phosphate solubilization and its potential applications for improving plant growthpromoting bacteria. Plant Soil 287:15-21

Rudulie DL, Bernard T (1986) Salt tolerance in Rhizobium: a possible role for betaines. FEMS Microbiol Rev 39:67-72

Ryden A, Lindberg M, Philipson L (1973) Isolation and characterization of two protease producing mutants from Staphylococcus aureus. J Bacteriol 116:25-32

Sadowsky MJ, Keyser HH, Bohlool BB (1983) Biochemical characterization of fast- and slow- growing rhizobia that nodulate soybeans. Int J Syst Bacteriol 33:716-722

Saldana G, Martinez-Alcantara V, Vinardell JM, Bellogin R, Ruiz-Sainz JE, Balatti PA (2003) Genetic diversity of fast-growing rhizobia that nodulate soybean (Glycine max L. Merr). Arch Microbiol 180:45-52

Samudin S, Kuswantoro H (2018) Effect of Rhizobium inoculation to nodulation and growth of soybean [Glycine max (L.) Merrill] germplasm. Legume Res 41(2):303-310

SAS (2000-2004) SAS Computer software package. SAS Institute Inc, NC 
Scholla MH, Elkan GH (1984) Rhizobium fredii sp. nov. a fast-growing species that effectively nodulates soybeans. I J Syst Bacteriol 34:484-486

Scott WO, Aldrich SR (1983) Planting and cropping systems. In: Modern soybean production, Second Ed. S and A publications Inc. Champain ILL. USA

Sertsu S, Bekele T (2000) Procedures for soil and plant analysis. National Soil Research Center Ethiopian Agricultural Research Organization, Addis Ababa

Sharma MK, Kumawat DM (2011) A study on evaluation of nitrogen fixation potential in soybean. Eur J Exp Biol 1:93-97

Shurtleff W, Aoyagi A (2009) History of soybeans and soy foods in Africa (1857-2009): extensively annotated bibliography and source book. Soyinfo Center.

Siddiqui Y, Meon S (2009) Effect of seed bacterization on plant growth response and induction of disease resistance in Chilli. Agric Sci China 8:963-971

Singh SK, Jaiswal SK, Vaishampayan A, Dhar B (2013) Physiological behavior and antibiotic response of soybean (Glycine max L.) nodulating rhizobia isolated from Indian soils. Afr J Microbiol Res 7:2093-2102

Singleton PW, Tavares JW (1986) Inoculation response of legumes in relation to the number and effectiveness of indigenous rhizobium populations. Appl Environ Microbiol 51:1013-1018

Singleton PW, Somasegaran P, Nakao P, Keyser HH, Hoben HJ, Ferguson PI. (1990). Applied BNF Technology: A Practical Guide for Extension Specialists. NifTAL Project/BNF Technologies, University of Hawaii. Module 5

Sisay B, Melkamu B, Birhan A, Adugna T, Kindu M, Endalkachew W (2019) Inoculation and phosphorus fertilizer improve food-feed traits of grainlegumes in mixed crop-livestock systems of Ethiopia. Agric Ecosyst Environ 279:58-64

Solomon T, Mohan L, Angaw T (2012) Effect of inoculation by Bradyrhizobium japonicum stains on nodulation, nitrogen fixation, and yield of soybean (Glycine max L. Merill.) varieties on nitisols of Bako Western Ethiopia. ISRN Agronomy 2012:1-8

Somasegaren P, Hoben HJ (1994) Handbook for Rhizobia: Methods in legumerhizobiumtechnology. Springer, New York

Temesgen D, Maluk M, James EK, lannetta PPM, Assefa F (2019) The functional characterisation of soybean (Glycine max L.) rhizospheric bacteria indigenous to Ethiopian soils. AJAR 14(33):1659-1673
Thies JE, Singleton PW, Bohlool BB (1991) Influence of the Size of Indigenous rhizobial populations on establishment and symbiotic performance of introduced rhizobia on field-grown legumes. Appl Environ Microbiol 57(1):19-28

Ulzen J, Abaidoo RC, Mensah NE, Masso C, AbdelGadir AH (2016) Bradyrhizobium inoculants enhance grain yields of soybean and cowpea in Northern Ghana. Front Plant Sci 7:1-9

Vincent JM (1970) A manual for practical study of root nodule bacteria. Blackwell Science Publication, Oxford

White D (1995) The physiology and biochemistry of prokaryotes. Oxford University Press, Oxford

Xu LM, Ge C, Cui Z, Fan H (1995) Bradyhizobium liaoningense sp. nov., Isolated from the Root Nodules of Soybeans. I I Syst Bacteriol 5:706-711

Yadav J, Verma JP, Rajak VK, Tiwari KN (2011) Selection of indigenous Rhizobium strains for seed inoculation of chickpea (Cicer aritenium L.) production. Bacteriol J 1:24-30

Yang JK, Zhou JC (2008) Diversity, phylogeny and host specificity of soybean and peanut bradyrhizobia. Biol Fertil Soils 44:843-851

Yi-you $L$ (2004) The soybean protein fibre - a healthy and comfortable fibre for the $21^{\text {st }}$ Century. Fibres Text East Eur 12:8-9

Young CC, Chang JY, Chao CC (1988) Physiological and symbiotic characterstics of Rhizobium fredii isolated from sub-tropical soils. Biol Fertil Soils 5:350-354

Youseif SH, Abd El-Megeed FH, Ageez A, Mohamed ZK, Shamseldin A, Saleh SA (2014) Phenotypic characteristics and genetic diversity of rhizobia nodulating soybean in Egyptian soils. Eur J Soil Bio 60:34-43

Zhang YM, Sui XH, Li YJ, Li QQ, Chen WX (2012) Bradyrhizobium huanghuaihaiense sp. nov., an effective symbiotic bacterium isolated from soybean (Glycine max L.) nodules. I J Syst Evo Microbiol 62:1951-1957

\section{Publisher's Note}

Springer Nature remains neutral with regard to jurisdictional claims in published maps and institutional affiliations.

\section{Submit your manuscript to a SpringerOpen ${ }^{\circ}$ journal and benefit from:}

- Convenient online submission

- Rigorous peer review

- Open access: articles freely available online

- High visibility within the field

- Retaining the copyright to your article

Submit your next manuscript at springeropen.com 